\title{
Sea-level rise along the Emilia-Romagna coast (Northern Italy) in 2100: scenarios and impacts
}

\author{
Luisa Perini $^{1}$, Lorenzo Calabrese ${ }^{1}$, Paolo Luciani $^{1}$, Marco Olivieri $^{2}$, Gaia Galassi $^{3}$, and Giorgio Spada ${ }^{3}$ \\ ${ }^{1}$ Servizio Geologico, Sismico e dei Suoli, Regione Emilia-Romagna, Bologna, Italy \\ ${ }^{2}$ Istituto Nazionale di Geofisica e Vulcanologia, Sezione di Bologna, Bologna, Italy \\ ${ }^{3}$ Dipartimento di Scienze Pure e Applicate (DiSPeA), Università degli Studi di Urbino Carlo Bo, Urbino, Italy
}

Correspondence: Giorgio Spada (giorgio.spada@gmail.com)

Received: 1 March 2017 - Discussion started: 13 March 2017

Revised: 22 September 2017 - Accepted: 25 October 2017 - Published: 13 December 2017

\begin{abstract}
As a consequence of climate change and land subsidence, coastal zones are directly impacted by sea-level rise. In some particular areas, the effects on the ecosystem and urbanisation are particularly enhanced. We focus on the EmiliaRomagna (E-R) coastal plain in Northern Italy, bounded by the Po river mouth to the north and by the Apennines to the south. The plain is $\sim 130 \mathrm{~km}$ long and is characterised by wide areas below mean sea level, in part made up of reclaimed wetlands. In this context, several morphodynamic factors make the shore and back shore unstable. During next decades, the combined effects of land subsidence and of the sea-level rise as a result of climate change are expected to enhance the shoreline instability, leading to further retreat. The consequent loss of beaches would impact the economy of the region, which is tightly connected with tourism infrastructures. Furthermore, the loss of wetlands and dunes would threaten the ecosystem, which is crucial for the preservation of life and the environment. These specific conditions show the importance of a precise definition of the possible local impacts of the ongoing and future climate variations. The aim of this work is the characterisation of vulnerability in different sectors of the coastal plain and the recognition of the areas in which human intervention is urgently required. The Intergovernmental Panel on Climate Change (IPCC) Fifth Assessment Report (AR5) sea-level scenarios are merged with new high-resolution terrain models, current data for local subsidence and predictions of the flooding model "in_CoastFlood" in order to develop different scenarios for the impact of sea-level rise projected to year 2100 . First, the potential land loss due to the combined effect of subsidence and sea-level rise is extrapolated. Second, the in-
\end{abstract}

crease in floodable areas as a result of storm surges is quantitatively determined. The results are expected to support the regional mitigation and adaptation strategies designed in response to climate change.

\section{Introduction}

The sea-level rise associated with global warming is a growing concern for the scientific community as well as for governments, the media and the public. Climate-driven sea-level rise has a direct impact on the coastal zones, with threatening consequences for the ecosystem and urbanisation. The causes of contemporary sea-level rise have been reviewed by Nicholls and Cazenave (2010), who have also identified, globally, the coastal areas that are particularly vulnerable to flooding. These include low-elevation coastal zones, densely populated areas where the natural or human-induced rate of subsidence is appreciable, and regions characterised by a limited adaptation capacity. In addition, higher mean sea levels are expected to amplify flooding caused by storm surges and hurricanes, with an enhanced impact on population (Nicholls et al., 1999). The last Intergovernmental Panel on Climate Change (IPCC) Fifth Assessment Report (AR5) has made a considerable progress toward an understanding of the 20th century sea-level rise and its variability on a global scale; furthermore, sea-level projections for the 21st century have been greatly improved (Church et al., 2013). Nevertheless, detailed projections of sea-level rise on regional and local scales are still hampered by the complex local response of 
the coastal system to sea-level rise (Cazenave and Cozannet, 2014; Hinkel et al., 2015).

In the general context outlined above, this work focuses on the possible effects of sea-level rise on the coastal area of Emilia-Romagna (E-R, Northern Italy), one of the administrative regions of Italy facing the northern Adriatic Sea (see Fig. 1). The Emilia-Romagna coastal plain has a crucial economical and naturalistic value. It is, indeed, the site of one of the largest tourism industries in Europe, the Riviera Romagnola, and it embraces the Po delta protected area, which was recently included in the Man and the Biosphere Programme by Unesco ${ }^{1}$. Characterised by a gentle slope, the E-R coastal plain is highly vulnerable as a result of (i) widespread coastal erosion, (ii) seawater intrusions related to sea-level rise, (iii) storm surges and (iv) land subsidence. These four major threats have been exacerbated by the human expansion that has occurred since the 1940s, when a rapid urbanisation and a strong exploitation of underground resources (water and gas) began (Lorito et al., 2010; Perini and Calabrese, 2010). The reader is referred to the recent work of Aucelli et al. (2016) for the coastal inundation risk assessment in the Volturno coastal plain in southern Italy, characterised by spread back-shore depressions and subsidence. On a nationwide scale, a detailed account for sea-level rise and potential drowning of the Italian coastal plains has been given by Antonioli et al. (2017). Finally, a sophisticated approach was taken by Wolff et al. (2016), who downscaled the Dynamic Interactive Vulnerability Assessment (DIVA) model (Hinkel et al., 2014) for the E-R case. This model considers the effects of mean-sea-level rise in terms of impacts on the population and on the existing assets. It also foresees that mitigation actions, as the building of dykes, will gradually accompany the sea-level rise projected to year 2100 .

The awareness by the local authority, i.e. the EmiliaRomagna Regional Administration (RER), that a holistic approach was desirable to properly manage the climaterelated risks at coastal areas motivated the setup of an integrated path, called "Gestione Integrata delle Zone Costiere" (GIZC), which led to the approval of specific guidelines ${ }^{2}$. This document recognises the need of putting the mitigation of local risk in the climate change framework, with a special attention to the sea-level rise issue. Subsequently, in 2007,

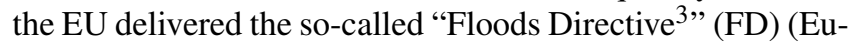
ropean Parliament and Council, 2007) aimed at reducing and managing the risks posed by floods to human health, the environment, cultural heritage and economic activity. The recent Ministry of the Environment guidelines on coastal pro-

\footnotetext{
${ }^{1}$ See goo.gl/gilyNE.

2"Linee Guida GIZC", deliberation of regional council no. $654 / 2005$.

${ }^{3}$ Directive 2007/60/EC on the assessment and management of flood risks (goo.gl/pzJ74o).
}

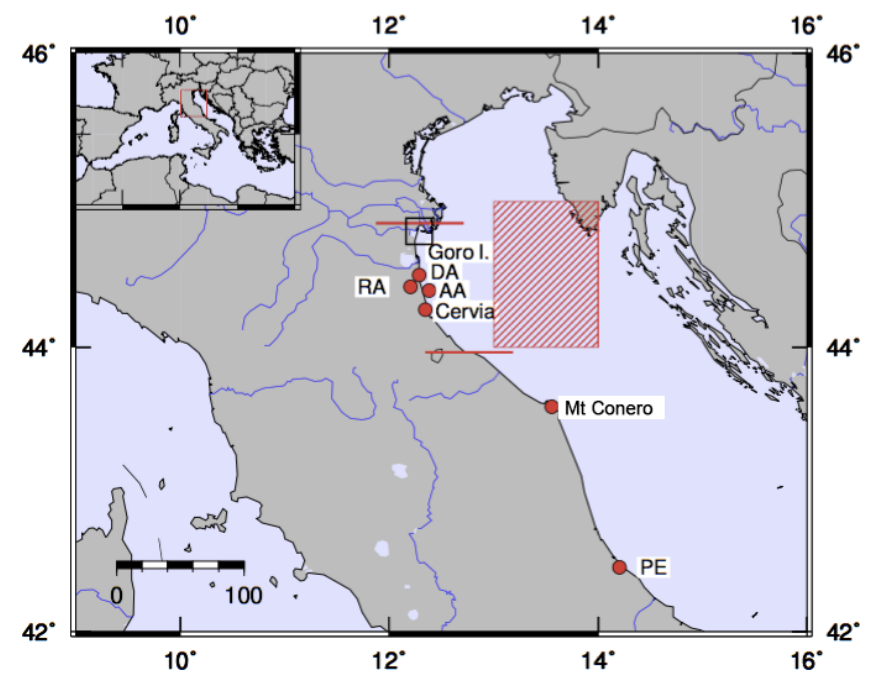

Figure 1. Map of the northern Adriatic Sea and of the surroundings. Horizontal ticks on the east coast of Italy mark the northern and southern limits of the E-R shoreline. The hatched rectangle shows the cell of the IPCC AR5 discretisation of the global oceans used to represent the projected sea-level change in front of the E-R coast (RA: Ravenna, AA: Angela-Angelina gas field, PE: Pescara). The town of Cervia divides the E-R coast into two sectors, referenced as north $(\mathrm{N})$ and south $(\mathrm{S})$ in the body of the paper. DA: Dosso degli Angeli gas field; Goro 1.: Goro lagoon

tection from erosion and climate change effects ${ }^{4}$, delivered in cooperation with coastal regions in 2016 and in accordance with the FD, also highlight recommendations of the Emilia-Romagna GIZC guidelines. The document notes that long-term climate change could not be excluded from the national and regional plans for the mitigation of the seawater flooding risks. These concepts are also included in the nationwide SNAC (National Strategy for the Adaptation to Climate Change $)^{5}$. The development of these national and transnational laws and guidelines drove the definition, by the EmiliaRomagna Regional Administration, of the "Path toward a strategy for the mitigation of climate changes" 6 . This path includes the study of the climate change impact on coastal zones and the identification of the most vulnerable areas by means of models and cartographic analyses.

Within the above multidisciplinary pathway, it is crucial to identify and characterise the most vulnerable portions of the coastal plain, on which actions should be focused at first. Local and short-term phenomena occurring in the E-R coastal plain and in its neighbourhoods have been put in a long-term framework, which also includes regional and global climate

\footnotetext{
${ }^{4}$ Linee Guida Nazionali per la difesa della costa dai fenomeni di erosione e dagli effetti dei cambiamenti climatici (goo.gl/QAL8iN).

${ }^{5}$ Strategia Nazionale di Adattamento ai Cambiamenti Climatici, 2014 (goo.gl/zCYV6C).

${ }^{6}$ Deliberation no. 2200/2015, Percorso verso una strategia di mitigazione dei cambiamenti climatici.
} 
change. The combined effects of climate-induced sea-level rise, of subsidence and of coastal storm events along the E-R shoreline aroused public attention two decades ago, following the 1992 IPCC Supplementary Report (Intergovernmental Panel on Climate Change, 1992). Bondesan et al. (1995) preliminarily investigated the impact of these IPCC scenarios for sea-level rise in the year 2100 , in combination with expected subsidence and trends for storm surges. They concluded that the area potentially affected by the risk of flooding was doomed to increase in the future. Along these lines, in the work of Gonella et al. (1998) a numerical model based upon geographic information system (GIS) tools was applied for the first time to the 1992 IPCC scenarios, considering storm surge return periods of 1,10 and 100 years. Their analysis was also extended to the risk assessment in terms of saltwater ingression and soil consumption. Recently, Antonioli et al. (2017) have used IPCC AR5 global projections to 2100 for sea-level rise with local assessment for subsidence derived from Global Positioning System and tide gauge data. These have provided regional scenarios for different parts of the low-elevation portion of the Italian peninsula, including the E-R coastal plain.

The main purpose of this work is the determination of the future impact of land subsidence and sea-level rise on the E-R coast. In particular, for the first time in this region, the focus will be on two aspects: (i) the loss of territories that are currently at, or above, mean sea level (case study 1, CS1) and (ii) the enlargement of the areas potentially affected by seawater flooding due to storms (case study 2, CS2). Our objective is twofold: (i) the identification of those portions of the E-R coast which potentially could be flooded by the end of current century, while also taking into account the effects of storm surges; and (ii) the comparison of the results with the current hazard map for the ingression of the sea that resulted from the FD. In the following, CS1 and CS2 are discussed, taking the geomorphological and geodynamic complexity of the area into account and adopting the mean-sea-level projections published in the IPCC AR5 (Church et al., 2013).

The paper is organised as follows. Section 2 describes the physical characteristic of the study region and the driving processes. The data and methods employed are presented in Sect. 3. The results, presented in Sect. 4 , are discussed in Sect. 5. Our conclusions are drawn in Sect. 6.

\section{Physical characteristics and driving processes}

The E-R coastal plain develops along the south-eastern margin of the Po Plain in Northern Italy; it is bounded to the north by the Po di Goro branch of the Po delta and to the south by the Apennine chain. The orientation of the chain and the direction of progradation of the Po river make the plain narrow to the south (a few kilometres in the EW direction) and broad to the north where it exceeds $40 \mathrm{~km}$ (see Fig. 2a). The shoreline is about $130 \mathrm{~km}$ long and is charac- terised by low-elevation sandy beach ridges occasionally associated with lagoons, wetlands and river mouths.

The coastal area and its shoreline can be divided into a northern $(\mathrm{N})$ and a southern $(\mathrm{S})$ sector, whose boundary can be placed around the town of Cervia (see Fig. 1). The different physical characteristics of the two sectors, which are of relevance for the determination of the response of the coastal area to the marine ingressions, are detailed in Perini and Calabrese (2010). The vulnerability of the entire coastal area is mainly caused by the absence of dunes and by their discontinuity, especially in the $\mathrm{S}$ sector. A further cause of vulnerability is the presence, particularly in the $\mathrm{N}$ sector, of wide areas that are currently below mean sea level. Moreover, the combination of subsidence with the natural retreat of the shoreline due to the reduction of the river sediment discharge is responsible for a widespread coastal erosion, both on shortand long-term timescales (Perini and Calabrese, 2010).

The human pressure and the underground exploitation of the E-R coastal plain and of its surroundings have enhanced the expected effects of climate change, and particularly of coastal storms. The risk for sea flood has been magnified by the urbanisation that, since the end of the second World War, has increased by $\sim 400 \%$ in terms of occupied area (Lorito et al., 2010). In front of most coastal towns and resorts, the dunes, which are the natural rampart against the sea flood and a natural reservoir of sand for the nourishment of the beaches, have been totally destroyed by urbanisation. In some cases the shoreline retreats have reached the buildings and infrastructures. This urbanisation, however, is mostly concentrated along a narrow area along the E-R coastal plain, bordering on the zone where normally most of the energy is dissipated during intense coastal storms.

The Emilia-Romagna shoreline is highly artificialised and shows different types of coastal flood defences. These are mainly composed by emerging or submerged longitudinal breakwaters and localised jetties, groynes and sea walls, especially in the Goro lagoon. In the $\mathrm{N}$ sector, following the extreme flooding event that occurred in 1966 (Perini et al., 2011), a long, $4 \mathrm{~m}$ high embankment was erected to protect the back shore at a distance ranging between 0.5 and $1.5 \mathrm{~km}$ from the shoreline. However, during the 1970s and 1980 s, the vulnerability of the area between the shoreline and the wall was not considered a concern and an intensive urbanisation took place there. In the S sector, on the other hand, no coastal defences have been erected against marine inundations, while the sparse flood protection dykes are only aimed at defending the local infrastructure from coastal storms. Against the coastal storms, it is common practice offseason (i.e. during the winter) to build temporary embankments along the beaches. These, if properly designed, play a crucial role in the attenuation and mitigation of the effect of coastal storms, in reducing the ingression of seawater in the back shore and in preventing erosion.

For each of the two sectors considered ( $\mathrm{N}$ and $\mathrm{S})$, the physical features of the E-R coastal plain are summarised 
(a)

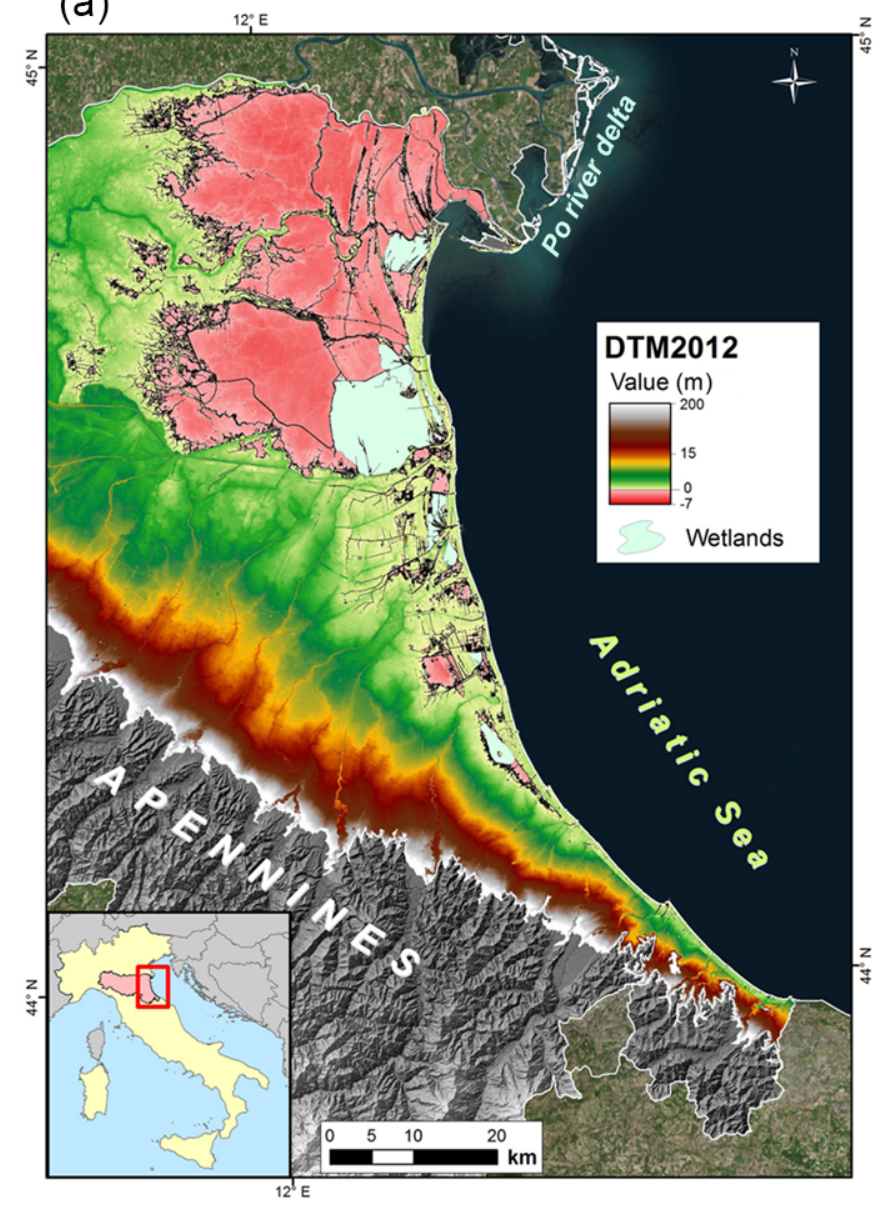

(b)

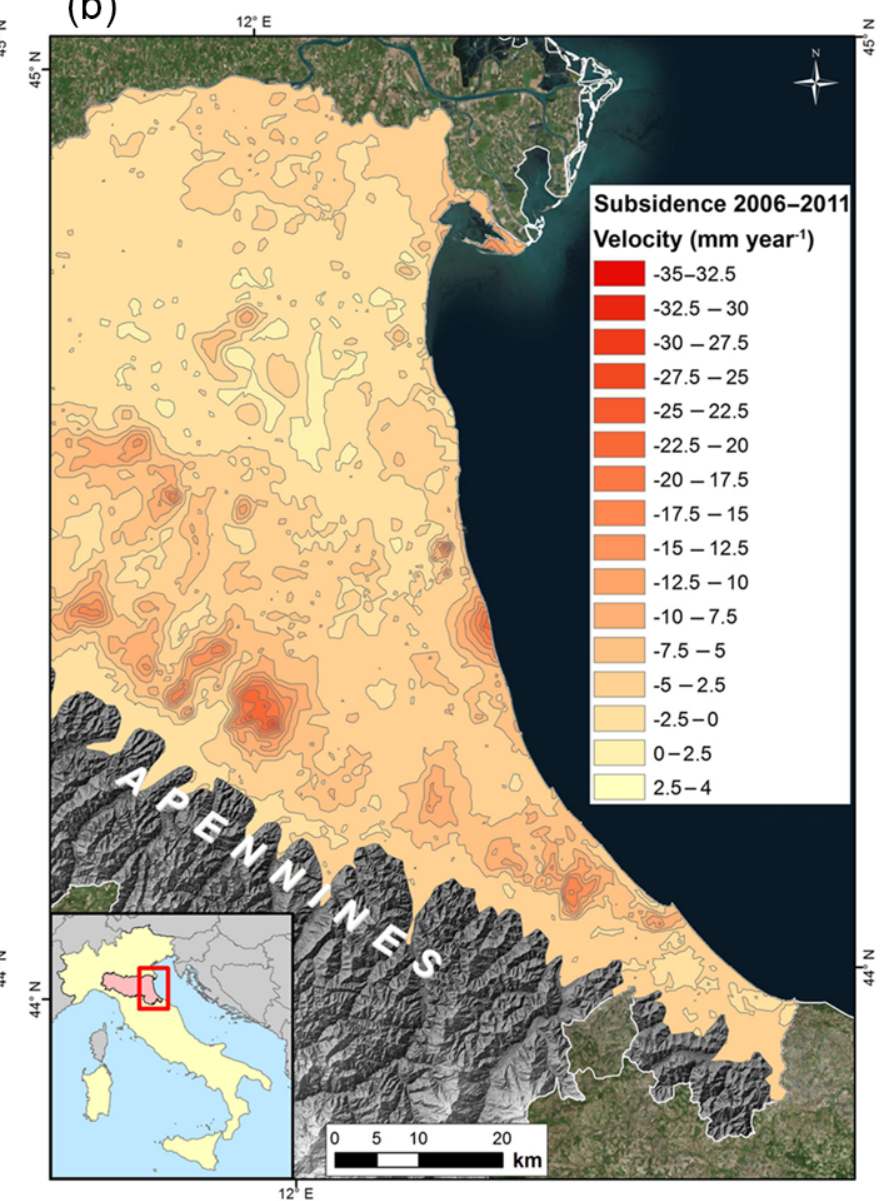

Figure 2. (a) The altimetry and morphology of the E-R coastal plain resulting from a high-resolution digital terrain model (DTM). The reference height in the map is the zero of the Italian geodetic network. The remarkable difference between the $\mathrm{N}$ and the $\mathrm{S}$ sectors in terms of the extension of lowlands is evident. (b) Subsidence rate map of the E-R coastal plain according to the interferometric synthetic aperture radar (InSAR) monitoring for the time period 2006-2011 (Bissoli et al., 2012).

Table 1. Summary of the physical characteristics of the E-R coast. The N and S sectors are defined in Fig. 1.

\begin{tabular}{|c|c|c|}
\hline & North sector $(\mathrm{N})$ & South sector $(\mathrm{S})$ \\
\hline Coastal plain width $(D)$ & $5<D<40 \mathrm{~km}$ (from south to north) & $0.8<D<5 \mathrm{~km}$ (from south to north) \\
\hline $\begin{array}{l}\text { Dominant elevation above } \\
\text { sea level }(H)\end{array}$ & $-1<H<1 \mathrm{~m}$ & $0<H<3 \mathrm{~m}$ \\
\hline Dry beach width $\left(D_{\mathrm{S}}\right)$ & $0<D_{\mathrm{s}}<300 \mathrm{~m}$ & $10<D_{\mathrm{s}}<180 \mathrm{~m}$ \\
\hline Average value $\left(\bar{D}_{\mathrm{s}}\right)$ & $\bar{D}_{\mathrm{s}}=60 \mathrm{~m}$ & $\bar{D}_{\mathrm{s}}=80 \mathrm{~m}$ \\
\hline Geomorphological features & $\begin{array}{l}\text { Beach ridges, dunes, lagoons, wetlands, } \\
\text { reclaimed areas, sand spits }\end{array}$ & $\begin{array}{l}\text { Beach ridges, dunes (only towards the } \\
\text { north), salt pans }\end{array}$ \\
\hline Shape of the shoreline & $\begin{array}{l}\text { Wavy, convexities at river estuaries, } \\
\text { more complex at river spits }\end{array}$ & $\begin{array}{l}\text { Straight with asymmetric wedges at Ce- } \\
\text { senatico and Rimini harbors }\end{array}$ \\
\hline Back-shore land use & $\begin{array}{l}\text { Urbanised areas, agriculture, vegetation } \\
\text { and wetlands }\end{array}$ & $\begin{array}{l}\text { Wide urbanised areas, agriculture and } \\
\text { vegetation }\end{array}$ \\
\hline Medium-long-term tendency & Variable, tending to rectify & Stable, with local changes \\
\hline
\end{tabular}


in Table 1. These include the main geometrical features (the coastal plain width $D$, and its elevation above mean sea level $H$ ), geomorphological characteristics, shapes and tendency, shoreline width $D_{\mathrm{S}}$ and average width $\bar{D}_{\mathrm{S}}$, and shoreline backside usage. Furthermore, in the following sections (Sect. 2.1, 2.2 and 2.3), we provide an account of the processes that are responsible for the coastal vulnerability of the area. These are (i) land subsidence, (ii) sea-level variability and (iii) coastal storms.

\subsection{Land subsidence}

For areas slightly above mean sea level, the main consequence of subsidence is an increased vulnerability to the effects of storm surges, since the progressive lowering of the ground will facilitate the marine ingression. Current average rates of land subsidence observed in the $S$ sector of the E$\mathrm{R}$ coastal plain, as well as in the southernmost part of the $\mathrm{N}$ sector, are close to $5 \mathrm{~mm} \mathrm{yr}^{-1}$. However, in some areas of the $S$ sector and particularly at the mouths of rivers and in the back shore of the Cesenatico and Rimini areas, they may exceed $\sim 10 \mathrm{~mm} \mathrm{yr}^{-1}$. In the $\mathrm{N}$ sector, rates of subsidence are smaller, typically in the range of 0 to $2.5 \mathrm{~mm} \mathrm{yr}^{-1}$, while in the area of the Po delta rates of $\sim 10 \mathrm{~mm} \mathrm{yr}^{-1}$ are again observed (Bissoli et al., 2012) (see Fig. 2b). Locally, land subsidence reaches $20 \mathrm{~mm} \mathrm{yr}^{-1}$ due to gas extraction. This occurs, in particular, at the Uniti (Fiumi Uniti) river mouth. These significant present-day rates can result in a total subsidence of 2-3 $\mathrm{m}$ in a century (Bondesan et al., 1995) as a result of the combined action of natural and anthropogenic factors.

The natural component of land subsidence is normally the result of tectonic activity, glacial isostatic adjustment (GIA) and sediments compaction caused by the variability in water content in various geological layers, resulting in a reduction of their volume. Various works have investigated the geological and tectonic evolution of the area (Pieri and Groppi, 1981; Ricci Lucchi et al., 1982), the effects of GIA (Lambeck et al., 2011), and the quantification of subsidence in the Po Plain and in the northern Adriatic coast (Carminati and Di Donato, 1999; Gambolati et al., 1999; Antonioli et al., 2009; Teatini et al., 2011a). These studies have concluded that the natural subsidence in the region is dominated by the effect of sediment compaction that, along the costal belt, can reach levels comparable to the anthropogenic component of land subsidence. Furthermore, subsidence of glacial isostatic origin has been shown to have presently a minor role along the E-R coastal plain (Stocchi and Spada, 2009).

The anthropogenic subsidence is a consequence of land use and soil exploitation that followed the second World War and is mainly caused by water pumping and gas extraction. These activities have produced a rapid increase in ground subsidence, with rates sometimes exceeding the natural values by 1 order of magnitude. For example, in the municipality of Ravenna (RA), the observed rate of subsidence rose from 5 (pre-war epoch) to $\sim 50 \mathrm{~mm} \mathrm{yr}^{-1}$ (after the war). A detailed discussion of the subsidence connected with the extraction activities can be found in Barends et al. (2005), Teatini et al. (2005) and Bonsignore et al. (2008). At present, following the reduction of most of the water extraction activities, the extraction-induced subsidence is mainly attributable to gas fields (Angela-Angelina, see Fig. 1), which are still in production. A comprehensive map of the expected regression for the northern Adriatic coastline in 2100 was published by Gambolati et al. (1998). They also estimated the extent of the floodable area as a result of the combined effects of subsidence and of a $50 \mathrm{~cm}$ increase in mean sea level, based upon a coarse digital terrain model (DTM) dataset (see Fig. 1.18 in Gambolati et al., 1998).

\subsection{Sea-level variability}

During last millennia, the history of the E-R coast, as well as the Adriatic Sea, has been characterised by a significant sealevel rise and variability. In response to the rapid sea-level rise following the end of the last glacial period, in the early Holocene the shoreline experienced a rapid migration from the current latitude of Pescara to approximately the presentday position of the coastline (Correggiari et al., 1996) (see Fig. 1). This was followed by a stabilisation of the shoreline close to its present position, although it has been recognised that, during the post-glacial period, small changes in the climate and in the eustatic component of sea level occurred on scales of decades and centuries (Bruckner, 1890; Friis-Christensen and Lassen, 1991). The migration of the shoreline toward the current position began between 4000 and 5000 years ago, driven by the progradation of the Po river delta and of the beach ridges. During this period, a slow subsidence was acting against the retreat of the seawater (Correggiari et al., 1996).

On timescales of decades to centuries, changes in the shoreline have been more complex but of smaller amplitude, with shifts up to a few kilometres, mainly driven by the dynamics of rivers (Calabrese et al., 2010) and connected with the ongoing climate change. During the last millennium, we note that the Medieval Climate Optimum (Veggiani, 1986) with a relative maximum in sea level (9th-10th century) followed by the Little Ice Age (16th-19th century) with larger sedimentary production and a marine regression (Marabini et al., 1993; Brázdil et al., 2005).

During last century, tide gauges located across the Adriatic Sea have indicated a regional rate of sea-level rise of $1.25 \pm 0.04 \mathrm{~mm} \mathrm{yr}^{-1}$ (Galassi and Spada, 2014b), which is slightly less than the global secular average (e.g. Spada and Galassi, 2012). However, significant cyclic variations with a period of $\sim 20$ years, associated with the Atlantic decadal oscillations, have been observed as well (Galassi and Spada, 2014b). Cerenzia et al. (2016) have recently studied the anomalous tide gauge record of Porto Corsini, which goes back to the late 1880 s and shows long-term rates of rela- 
tive sea-level change of $8-9 \mathrm{~mm} \mathrm{yr}^{-1}$. These rates, which strongly deviate from the typical rates across the Adriatic Sea, demonstrate an important role of local land subsidence, which is also driven by anthropogenic factors as water extraction and soil compaction (Teatini et al., 2005).

For our subsequent analysis, it is important to note that in the northern Adriatic Sea the effects of GIA on relative and absolute sea-level change are currently relatively minor, i.e. of a few fractions of $\mathrm{mm} \mathrm{yr}^{-1}$ (Stocchi and Spada, 2009; Galassi and Spada, 2014b; Bonaduce et al., 2016). Future rates of GIA-induced sea-level variations across the whole Mediterranean Sea (Galassi and Spada, 2014a) will not change with respect to current trends since this phenomenon only evolves on millennial timescales.

\subsection{Coastal storms}

The entire northwestern coast of the Adriatic Sea is exposed to a high degree of inundation risk by sudden water level increase associated with coastal storms (Harley, 2017). The E-R coastal plain can be considered a low-energy environment with significant wave height $H_{\text {sig }}=0.4 \mathrm{~m}$ (period $T_{\text {peak }}=4 \mathrm{~s}$ ) and a semidiurnal and micro-tidal regime, with an average maximum excursion of $0.7-0.8 \mathrm{~m}$ (IDROSER S.p.A., 1996; Harley et al., 2012). Wind waves are characterised by a significant height, with $H_{\text {sig }}=3.3 \mathrm{~m}$ for 1 year return period (Armaroli et al., 2009), which is most frequently associated with the Bora weather conditions blowing from the east-northeast sectors. South-easterly winds (Scirocco) are generally not as intense as those generated by Bora winds (Deserti et al., 2006), due to sheltering produced by the Conero headland $(\sim 100 \mathrm{~km}$ to the south, see Fig. 1) and to the comparatively weak Scirocco. Nevertheless, Scirocco is the main driver of storm surge, causing the push of water all along the Adriatic Sea.

A detailed analysis of the storm surges was carried out by Masina and Ciavola (2011) using the tide gauge data from Porto Corsini (RA). Their analysis has identified extreme levels of $0.85,1.05$ and $1.28 \mathrm{~m}$ on mean sea level for a return period of 2, 10 and 100 years, respectively. The corresponding non-tidal residuals, computed for the same return periods, are $0.61,0.79$ and $1.02 \mathrm{~m}$ on mean sea level; such values are in use in E-R region for the computation of total water level in the flooding scenarios used for the FD maps (Perini et al., 2012). In the occurrence of storm surges, however, the coastal sea level can vary significantly with respect to the predicted combination of tide and wave. This is the result of the coarse resolution of the model with respect to local morphology and of the spatial variability in wave characteristics along the coastline. A statistical analysis of the comprehensive dataset of coastal storms during the period 1946-2010 (Perini et al., 2011) allowed for the definition of threshold values for wind waves and surges above which significant events, in terms of effects on population, landscape and urban structures, were recorded (Armaroli et al., 2012). These thresholds have been in use in the "coastal alert" procedure adopted by the E-R Regional Civil Defence Agency since 2012.

The stronger impacts are those associated with the coupling between winds from the first quadrant (N and NE) and exceptional tide peaks, known as "acqua alta" (Pirazzoli, 1981). The latter, indeed, appear to be crucial for the occurrence of coastal flooding (Perini et al., 2011). During the observation period 1946-2010, the most critical season was in late autumn (November and December), while in the last five years these events were recorded even in February. The most relevant event was that of November 1966 (Malguzzi et al., 2006; Trincardi et al., 2016), which impacted the whole northern Adriatic coast (De Zolt et al., 2006). This boosted the completion of most of artificial defences currently in place along the E-R coastal plain. With respect to the damages, these events commonly affect the touristic infrastructures along the coast (e.g. the resorts located along the beaches) as a result of the combination of flooding and of beach erosion. In some cases, the effects are exacerbated by the overflow of the rivers and channels whose discharge is obstructed by the storm surge, causing flooding in the surrounding urbanised areas and consequently increasing the impact on infrastructure and population. The complex factors outlined above have prompted us to simulate complex meteorological event scenarios, taking into account the main parameters, namely surge, astronomical tide and wave setups, which are already considered in the application of the FD.

\section{Data and methodologies}

The purpose of this work is to analyse the impact of the predicted relative sea-level change in 2100 along the E-R coastal plain. Two distinct aspects are modelled and discussed. The first is the increase in the extension of land with elevation below mean sea level and possibly of submerged areas, while the second is the effect of storm surges in terms of floodable areas. In both cases, the combined effects of sea-level rise and subsidence are properly taken into account. In the following sections we describe the sea-level projections that have been employed in this work (Sect. 3.1), some fundamental assumptions in modelling (Sect. 3.2) and the details of the models adopted (Sect. 3.3).

\subsection{Projected mean sea level}

For an assessment of future sea-level rise, we adopt the Representative Concentration Pathway (RCP) scenarios reported in the IPCC AR5 (Church et al., 2013). Through the Coupled Model Intercomparison Project Phase 5, the IPCC AR5 has defined RCPs that account for the evolution of the climate variables and in particular of the $\mathrm{CO}_{2}$ concentration. The RCPs are used for climate modelling to describe four distinct future climate scenarios, characterised by different 
amounts of greenhouse gas emission. The four RCPs, 2.6, $4.5,6.0$, and 8.5 , are named after the possible range of radiative forcing values in the year 2100 relative to pre-industrial values, i.e. $+2.6,+4.5,+6.0$ and $+8.5 \mathrm{~W} \mathrm{~m}^{-2}$ (see Van Vuuren et al., 2007; Clarke et al., 2007; Fujino et al., 2006; Riahi et al., 2007, respectively).

The global mean-sea-level rise predicted for the four RCPs for the time interval 2081-2100 with respect to 1986-2005 is given in Table 2, whereas the projected sea-level rise is shown in Fig. 3. Table 2 also shows values of sea-level rise expected across the Adriatic and the Mediterranean Sea, which are obtained by averaging the AR5 sea-level rise grids downloaded from the Integrated Climate Data Center $(\mathrm{ICDC})^{7}$. We note that values of sea-level rise expected across the Adriatic Sea are systematically lower than those relative to the Mediterranean Sea. These, in turn, do not exceed the globally averaged values. Therefore, the use of globally averaged values for the IPCC projections like in Antonioli et al. (2017) would overestimate, along the E-R coast, the total amount of sea-level rise.

To focus on the northern Adriatic Sea, we have extracted from the global AR5 maps of the mean-sea-level projections for the grid cell closest to the E-R coast, namely the one centred at latitude $44.5^{\circ} \mathrm{N}$ and longitude $13.5^{\circ} \mathrm{E}$ (see Fig. 1). For any RCP, the E-R coast sea-level-rise values are found to be slightly lower than those pertaining to the whole Adriatic Sea. We are aware that in semi-enclosed basins like the Mediterranean Sea the ocean model component of sea-level rise could be affected by a limited precision, since the number of models contributing to the "ensemble mean" in these boxes is suboptimal (M. Carson, personal communication, 2013). However, we have kept these local projections since the members of the ensemble used to obtain them to provide predictions that are broadly consistent with those in the nearby Atlantic Ocean boxes. In the Adriatic Sea cell considered, the assessed GIA component of future relative sea-level rise is $-0.022 \pm 0.005 \mathrm{~m}$ in the years $2081-2100$ with respect to 1986-2005, where the uncertainty arises from the different predictions of two independently developed GIA models ${ }^{8}$.

\subsection{Assumptions}

The phenomena associated with long-term sea-level rise depend on geodynamic, morphodynamic, hydrodynamic and sedimentary factors. In consideration of the challenge of creating a model that accounts for all the aspects of the problem and to limit the computational burden, we have decided to take into account only the changes in the topography due to subsidence, which is the best monitored driving process along the coast. Moreover, several assumptions are necessary

\footnotetext{
${ }^{7}$ See goo.gl/QGV5md.

${ }^{8}$ See the README.txt at ftp://ftp.icdc.zmaw.de/ar5_sea_level_ rise/.
}

Table 2. Sea level predicted during the time interval 2081-2100 with respect to 1986-2005, according to the four IPCC AR5 RCPs. The Adriatic and Mediterranean values are averaged values across these seas. These projections do not include the GIA component of sea-level change.

\begin{tabular}{rrrrr}
\hline RCP & $\begin{array}{r}\text { E-R coast } \\
(\mathrm{m})\end{array}$ & $\begin{array}{r}\text { Adriatic } \\
(\mathrm{m})\end{array}$ & $\begin{array}{r}\text { Mediterranean } \\
(\mathrm{m})\end{array}$ & $\begin{array}{r}\text { Global } \\
(\mathrm{m})\end{array}$ \\
\hline 2.6 & $0.30 \pm 0.07$ & $0.31 \pm 0.01$ & $0.36 \pm 0.02$ & $0.38 \pm 0.15$ \\
4.5 & $0.34 \pm 0.09$ & $0.37 \pm 0.01$ & $0.42 \pm 0.03$ & $0.45 \pm 0.16$ \\
6.0 & $0.33 \pm 0.08$ & $0.36 \pm 0.02$ & $0.42 \pm 0.03$ & $0.47 \pm 0.16$ \\
8.5 & $0.45 \pm 0.12$ & $0.48 \pm 0.02$ & $0.57 \pm 0.03$ & $0.60 \pm 0.19$ \\
\hline
\end{tabular}

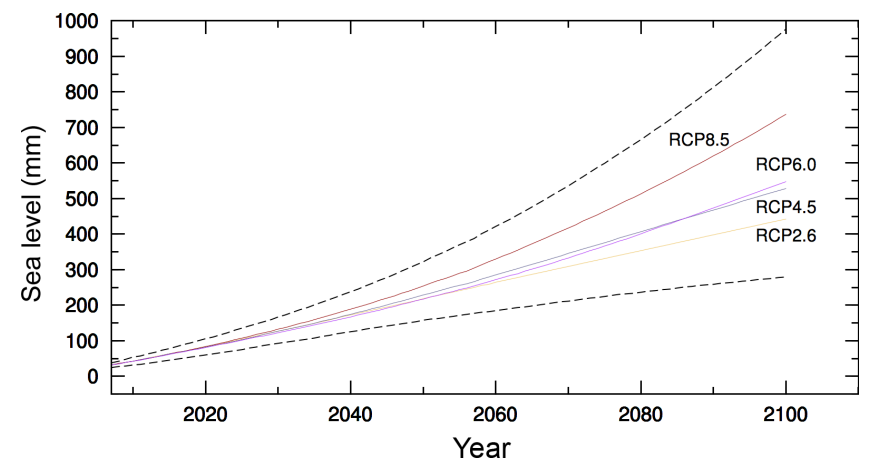

Figure 3. Sea-level pathways according to IPCC AR5. Dashed lines show the lower and the upper limits of the projections, corresponding to the upper limit of RCP 8.5 and to the lower limit of RCP 2.6. Projections are referred to the average sea-level values in the period 1986-2005.

to control possible sources of uncertainty, as well as to ease the interpretation of the results.

Specifically, in the process of modelling the effects of sealevel rise in the year 2100 (CS1), it is assumed that (i) no human intervention, such as the reconstruction of the dunes system and the placement of new artificial barriers, occurs (no action hypothesis); (ii) the local rates of subsidence remain constant over time and equal to those currently observed; and (iii) changes in the coast morphology are only a function of the rates of subsidence (this implies, in particular, that reshaping of the beaches as a result of morphodynamic processes will not be considered).

In CS2, a coastal storm scenario is considered, combining the effects of wave and storm surge. In addition to the three assumptions adopted for CS1, in CS2 it is assumed that the coastal storm conditions in 2100 are unchanged with respect to the present ones. It is worth noting that diverging future predictions for the rate of storm surges expected along the E-R coastal plain have been proposed based on different analyses. In the framework of the MICORE project ${ }^{9}$, and by means of time series analysis, Ciavola et al. (2011) have evidenced a tendency to increase in the rate of storm surges over

\footnotetext{
${ }^{9}$ See http://www.micore.eu/.
} 
Table 3. Description of the four input models employed for the definition of case studies CS1 and CS2. PNT stands for Piano Nazionale di Telerilevamento (National remote sensing plan).

\begin{tabular}{lrrll}
\hline Input dataset name & $\begin{array}{r}\text { Interpolated } \\
\text { points }\end{array}$ & $\begin{array}{r}\text { Altimetric } \\
\text { tolerance }\end{array}$ & $\begin{array}{l}\text { Output dataset } \\
\text { name }\end{array}$ & Grid size \\
\hline Lidar 2008 PNT & $2 \mathrm{p} \mathrm{m}^{-2}$ & $\pm 15 \mathrm{~cm}$ & DTM 2008 PNT & $2 \mathrm{~m} \times 2 \mathrm{~m}$ \\
Lidar 2010 RER & $4 \mathrm{p} \mathrm{m}^{-2}$ & $\pm 10 \mathrm{~cm}$ & DTM 2010 RER & $1 \mathrm{~m} \times 1 \mathrm{~m}$ \\
Lidar 2012 ENI & $4 \mathrm{p} \mathrm{m}^{-2}$ & $\pm 10 \mathrm{~cm}$ & DTM 2012 ENI & $1 \mathrm{~m} \times 1 \mathrm{~m}$ \\
PS-InSAR 2006-2011 PNT & $1 \mathrm{p} / 26 \mathrm{~m}^{2}$ & $\pm 2 \mathrm{~mm}$ & DVMM & $5 \mathrm{~m} \times 5 \mathrm{~m}$ \\
\hline
\end{tabular}

time, with unvaried storminess. Additionally, using a different approach based on climate models, Lionello et al. (2012) have predicted a decrease in storminess.

\subsection{Modelling}

The modelling is based on a GIS cartographic system exploiting the RER database. This provides a quick sketch of the apparent effects of sea-level rise, highlighting those areas where the impacts could be more critical. To describe the land surface, we have made use of a digital terrain model, incorporating lidar (Light Detection and Ranging) renderings and a digital vertical movement model (DVMM), at various spatial resolutions. A comprehensive summary of the datasets used is gathered in Table 3 and described below.

\subsubsection{Case study 1}

In CS1, for the determination of the areas with elevation below the mean sea level, the datasets in Table 3 have been merged in a DTM with a $5 \mathrm{~m} \times 5 \mathrm{~m}$ planimetric resolution (DTM2012-RER). This DTM has been preferred to a more detailed and complex digital surface model that incorporates lidar renderings including infrastructures, buildings and vegetation. Specific tests have confirmed that the former provides more realistic results. The DVMM is the result of the interpolation of data acquired by means of PS-InSAR ${ }^{10}$ (Bissoli et al., 2012). This DVMM has been used to project the expected subsidence in 2100 on a $5 \mathrm{~m} \times 5 \mathrm{~m}$ grid. The expected total vertical displacement in 2100 results from the assumption of constant rates of subsidence equal to those currently observed. The DTM2100 has been obtained by adding the total displacement to the DTM2012-RER.

In the framework of CS1, the sea-level variation $S$ in the year 2100 is expressed as the combination of three components:

$S^{\mathrm{CS} 1}(\omega)=S_{\mathrm{RCP}}+S_{\mathrm{GIA}}+S_{\mathrm{SUB}}(\omega)$,

where $\omega=(\theta, \lambda)$ with $\theta$ and $\lambda$ denoting colatitude and longitude, respectively; $S_{\mathrm{RCP}}$ is the contribution according to a specific RCP; $S_{\text {GIA }}$ is the GIA contribution; and $S_{\mathrm{SUB}}$ accounts for the effects of subsidence. Note that $S_{\mathrm{GIA}}$ and $S_{\mathrm{RCP}}$

\footnotetext{
${ }^{10}$ goo.gl/OQZE1a.
}

are assumed to be constant for the study area, while $S_{\mathrm{SUB}}$ is spatially variable along the E-R coast (see Fig. 2, right frame).

Starting from Eq. (1), two different scenarios have been defined. The first, referred to as the $\mathrm{H}$ scenario, corresponds to the $S_{\mathrm{RCP}}$ value associated with RCP8.5 plus $1 \sigma$ (i.e. $0.57 \mathrm{~m}$ ). The second, referred to as the $\mathrm{L}$ scenario, is based on RCP 2.6 minus its $1 \sigma$ (i.e. $0.23 \mathrm{~m}$, see Table 2). For both scenarios, the contribution of subsidence is

$S_{\mathrm{SUB}}(\omega)=r_{\mathrm{SUB}}(\omega) \Delta t$,

where $r_{\mathrm{SUB}}(\omega)$ represents the rate of subsidence at a given location (in metres per year) and $\Delta t$ is the elapsed time span in years. Furthermore, according to the IPCC AR5 assessment (see Sect. 3.1 above), the projected GIA component is

$S_{\mathrm{GIA}}=-0.022 \pm 0.005 \mathrm{~m}$.

Thus, Eq. (1) gives

$S_{\mathrm{H}}^{\mathrm{CS} 1}(\omega)=0.55 \mathrm{~m}+S_{\mathrm{SUB}}(\omega)$

and

$S_{\mathrm{L}}^{\mathrm{CS} 1}(\omega)=0.21 \mathrm{~m}+S_{\mathrm{SUB}}(\omega)$

for scenarios $\mathrm{H}$ and $\mathrm{L}$, respectively.

\subsubsection{Case study 2}

The objectives of CS2 are (i) the determination of the potential floodable areas in the year 2100 combining the effects of waves and storm surges and (ii) the comparison of these results with the hazard map for the seawater flooding processed in the framework of the FD (European Parliament and Council, 2007). This topic has a crucial impact in the Emilia-Romagna region, in view of the continuous loss of natural areas and the strong impact that a possible flooding may have on urban areas and on the tourism infrastructures. This methodology, which follows the approach adopted for CS1, is based on the modelisation of the future topographic surface and on the simulation of the flooding as a result of sea-level rise in scenarios $\mathrm{H}$ and $\mathrm{L}$ described above.

To effectively represent the impact of storm surges in the year 2100, the sea-level rise $S(\omega)$ predicted by Eqs. (4) and 
(5) is combined with the typical $S_{\text {STS }}$ run-up associated with characteristic storms in the region; that is,

$S_{\mathrm{H}, \mathrm{L}}^{\mathrm{CS} 2}(\omega)=S_{\mathrm{H}, \mathrm{L}}^{\mathrm{CS} 1}(\omega)+S_{\mathrm{STS}}$,

where $S_{\mathrm{STS}}$ is the total seawater level at the shoreline during coastal storms, calculated by combining the effects of surge, of the astronomical tide and of the wave setup. For the $S_{\mathrm{STS}}$ component of sea-level change, three scenarios have been adopted in order to process the hazard maps as requested by the FD. Each of them is associated with a different return period: frequent (10-year return period, P3), less frequent (100 years, $\mathrm{P} 2)$ and rare ( $\gg 100$ years, $\mathrm{P} 1$; see Table 4$)$ (Perini et al., 2012, 2016; Salerno et al., 2012).

This study is based on the GIS model named in_CoastFlood ${ }^{11}$ developed by Servizio Geologico, Sismico, e dei Suoli of the Emilia-Romagna region (SGSS-RER) (Perini et al., 2012), which merges the sea surface in the different weather conditions with the land topography (DTM lidar). A damping was applied as a function of the distance from the shoreline, with the exception of those areas which are not directly connected to the sea (Perini et al., 2012; Salerno et al., 2012). Different tests have been applied to validate the model and to choose the most appropriate scenario. This resulted in the selection of $\mathrm{P} 2$, which is the one with a return period of 100 years (a standard in the field of country planning) and characterised by more robust reference values. Scenario P3 was discarded since it affects only a limited portion of the coast, while P1 was discarded because its return period ( $\gg 100$ years) is not clearly defined from a statistical standpoint (Perini et al., 2016).

Once the reference values have been selected (P2), some local tests are performed to verify if short-term scenarios are worth considering, as they are mainly used in urban planning. The tests have shown that short-term scenarios (e.g. P2 in combination with the pessimistic "high-end" scenario projected to year 2030) have low significance in terms of changes in the floodable areas when compared to those reported in the map for P3 at present, and as a result shortterm effects were discarded. Then we used the most detailed DTM available (DTM lidar by ENI, 2012) whose resolution $(1 \mathrm{~m} \times 1 \mathrm{~m})$ exceeds the one used for CS1. The choice of this different dataset was motivated by its higher resolution, which is necessary to run the in_CoastFlood model. The model has been used to quantify the change in floodable areas by storm surges in 2012 (P2DTM12, present scenario) and 2100 (P2DTM2100, future scenario).

The importance of high-resolution data and models has been also emphasised by Wolff et al. (2016), who first downscaled the global DIVA approach to the case study of the E-R coastal plain. As pointed out in the introduction, Wolff et al. (2016) performed a similar study on the E-R costal plain. A comparison with our results below is not straightforward, since their work was mainly aimed at testing the sensitivity

\footnotetext{
${ }^{11}$ See goo.gl/qxVAWY.
}

Table 4. Total water elevation for the different types of sea storms considered in the FD and corresponding return periods (Perini et al., 2012, 2016; Salerno et al., 2012).

\begin{tabular}{lrr}
\hline Type of surge & $\begin{array}{r}\text { Return period } \\
\text { (years) }\end{array}$ & $\begin{array}{r}\text { Sea surface elevation } \\
(\mathrm{m})\end{array}$ \\
\hline Frequent (P3) & 10 & 1.49 \\
Less Frequent (P2) & 100 & 1.81 \\
Rare (P1) & $\gg 100$ & 2.50 \\
\hline
\end{tabular}

of DIVA in such a complex local case study, with attention to the impact on population and potential economical loss. What is relevant for the purpose of our work is their conclusion of the key role of detailed DTM elevation models to provide realistic assessments on a regional scale. In general, previous impact assessments performed in the same region are based on a methodology that compares water levels to terrain elevation, i.e. the "bathtub" method. On the contrary, the model employed in this work incorporates the bathtub method while also accounting for the hydrological connectivity between grid cells; only cells directly connected to the sea and with inundated nearby cells are considered flood prone.

To optimise our computations and for ease of understanding, the simulation has been performed across five distinct areas, highlighted in Fig. 4. From south to north, the areas range from Cattolica to Rimini (Area 1), from Rimini to Cesenatico (2), from Cesenatico to the Uniti river (3), from the Uniti river to Porto Garibaldi (4) and from Porto Garibaldi to Gorino (5). In Sect. 5 the results are gathered to provide a comprehensive overview on the full E-R regional scale.

\section{Results}

\subsection{Results for CS1}

The aim of this section is to determine those areas whose elevation in 2100 would move from above to below mean sea level by means of realistic estimates of the relative height of the ground. Henceforth we consider the $\mathrm{H}$ scenario, which implies a relative sea-level rise of about $55 \mathrm{~cm}$ in the year 2100.

A first analysis has been performed considering the E-R portion of the Po Plain having an extension of $\sim 9300 \mathrm{~km}^{2}$. On the basis of this, we have computed the variation of land with height above mean sea level by intersecting DTM2100 with the sea level in 2100 , which is obtained by shifting the present chart datum by $+55 \mathrm{~cm}$ (see Fig. 5). As summarised in Table 5, the effect of subsidence would contribute to the loss of $\sim 101 \mathrm{~km}^{2}$ of land above mean sea level, whereas considering the combined effect of subsidence and sea-level rise ( $\mathrm{H}$ scenario) the extension of the areas below mean sea level could reach $\sim 346 \mathrm{~km}^{2}$. It is apparent from Fig. 5 that the difference is only restricted to the coastal plain and that 


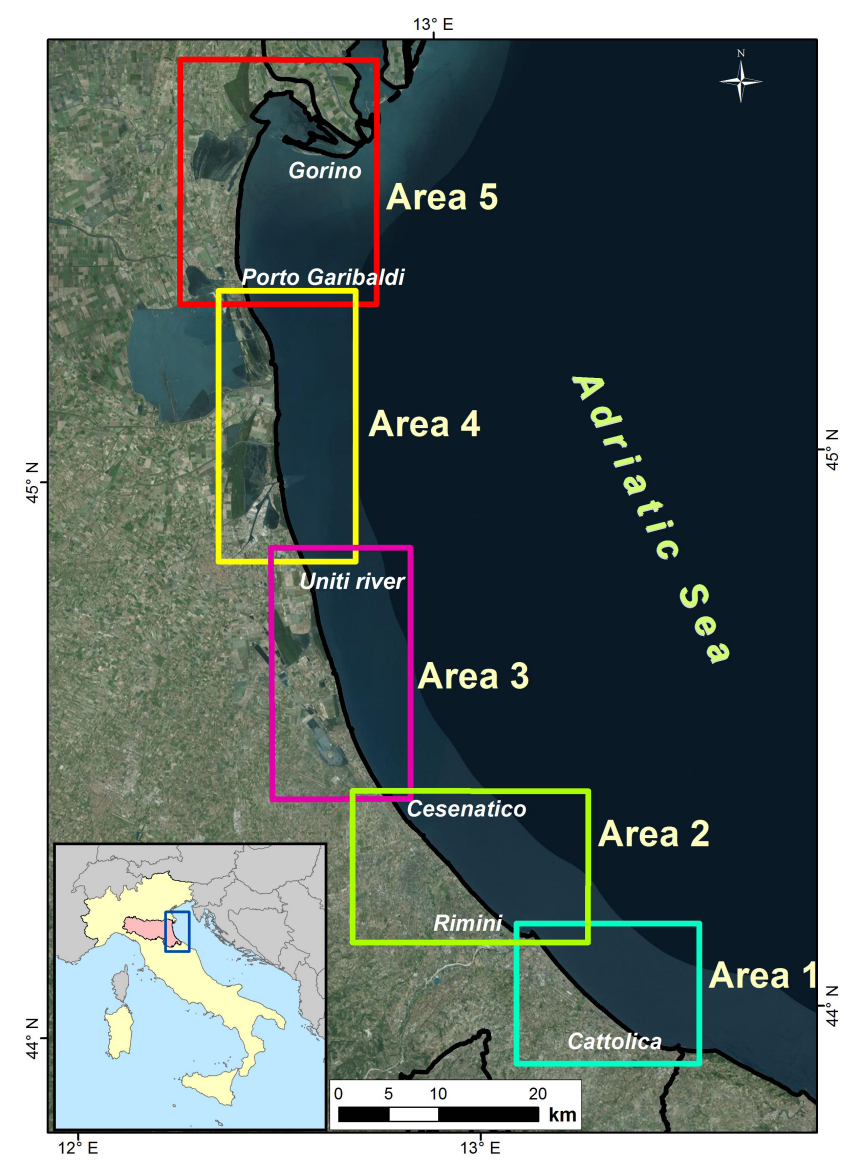

Figure 4. Location and boundaries of the five areas (areas 1 to 5) on which the E-R coastal plane has been divided.

large discrepancies exist between the $\mathrm{N}$ and the $\mathrm{S}$ sectors of the E-R coast. For this reason, we opted for a more detailed analysis by splitting the E-R coastal plain, whose total area is $\sim 3043 \mathrm{~km}^{2}$, into three sectors that differ for the morphology and for the response to the scenarios, i.e. the Ferrara, Ravenna and Rimini sectors. In the $\mathrm{H}$ scenario, Figure 5 shows the extent of the areas that will be located below mean sea level in the year 2100 (red). In the same Figure, the areas that today are below mean sea level are marked in yellow. The largest portion of potentially lowland areas in the year 2100 is limited to the Ravenna district (right frame in Fig. 5). This is a result of the high rates of subsidence observed in the area, which is characterised by a low elevation above mean sea level (see Table 6). It is important to underline that the submerged areas mostly consist of land not directly connected to the sea (lowland areas or polders).

\subsection{Results for CS2}

The maps obtained for CS2 (see Figs. 6 to 10) show a large increase in the risk of flooding during coastal storms along the whole E-R coast, in particular in Area 3, from Ravenna to Cesenatico. For the areas 1 to 5 , we now describe in detail
Table 5. Areas expected to be above (a.m.s.l.) and below mean sea level (b.m.s.l.) in the year 2100 compared to year 2012.

\begin{tabular}{lrrr}
\hline Year & $\begin{array}{r}\text { Area a.m.s.l. } \\
\left(\mathrm{km}^{2}\right)\end{array}$ & $\begin{array}{r}\text { Area b.m.s.l. } \\
\left(\mathrm{km}^{2}\right)\end{array}$ & $\begin{array}{r}\text { Lost area a.m.s.l. } \\
\left(\mathrm{km}^{2}\right)\end{array}$ \\
\hline 2012 & 8083.8 & 1216.4 & \\
$2100^{\mathrm{a}}$ & 7982.5 & 1318.3 & 101 \\
$2100^{\mathrm{b}}$ & 7737.6 & 1563.2 & 346 \\
\hline
\end{tabular}

a Only subsidence; ${ }^{\mathrm{b}}$ subsidence and sea-level rise.

Table 6. Detail of the future areas below sea level compared to year 2012.

\begin{tabular}{lrrr}
\hline Area & $\begin{array}{r}\text { Year 2012 } \\
\mathrm{km}^{2}\end{array}$ & $\begin{array}{r}\text { Year 2100 } \\
\mathrm{km}^{2}\end{array}$ & $\begin{array}{r}\text { Difference } \\
\mathrm{km}^{2}\end{array}$ \\
\hline Ferrara & 1143.32 & 1331.41 & 188.09 \\
Ravenna & 72.00 & 224.28 & 152.28 \\
Rimini & 0.72 & 6.34 & 5.61 \\
\hline
\end{tabular}

the increase in the floodable areas in the case of a storm surge with respect to the current scenario in 2012 (P2-DTM2012).

\subsubsection{Area 1}

In Area 1 (Fig. 6), the effects of subsidence are found to be very small in comparison with other areas; they result in an increase in the floodable area of $+47 \%$ with respect to the one predicted by model P2-DTM12. In the "low-end" and "high-end" sea-level scenarios projected to year 2100, these values increase to +85 and $+141 \%$, respectively. Remarkably, the area mostly affected by the sea-level component in comparison to subsidence is the centre of the town of Rimini, but the mouths of the rivers are also impacted. In Area 1, the extension of the floodable area is limited to $50-100 \mathrm{~m}$ landward with respect to that predicted by P2-DTM12.

\subsubsection{Area 2}

The results for Area 2 are shown in Fig. 7. Compared with other areas, Area 2 is characterised by smaller rates of subsidence, smaller depressed regions and higher averageelevations above the sea level, which naturally mitigates the combined effect of subsidence and of sea-level rise. The increase in the areas exposed to potential flooding in the year 2100 is limited to $+65 \%$ with respect to present for the only effect of subsidence, while for the $\mathrm{L}$ and $\mathrm{H}$ scenarios we obtain +102 and $+167 \%$, respectively, while also including the effects of land subsidence. From the map in Fig. 7, we recognise that, from the northern border to the Uso river mouth, the extension of the area at risk of flooding is dominated by the effects of subsidence. South of the Uso river mouth, the opposite occurs, with a dominating effect of sea-level rise especially for the high-end scenario. We note that some large 

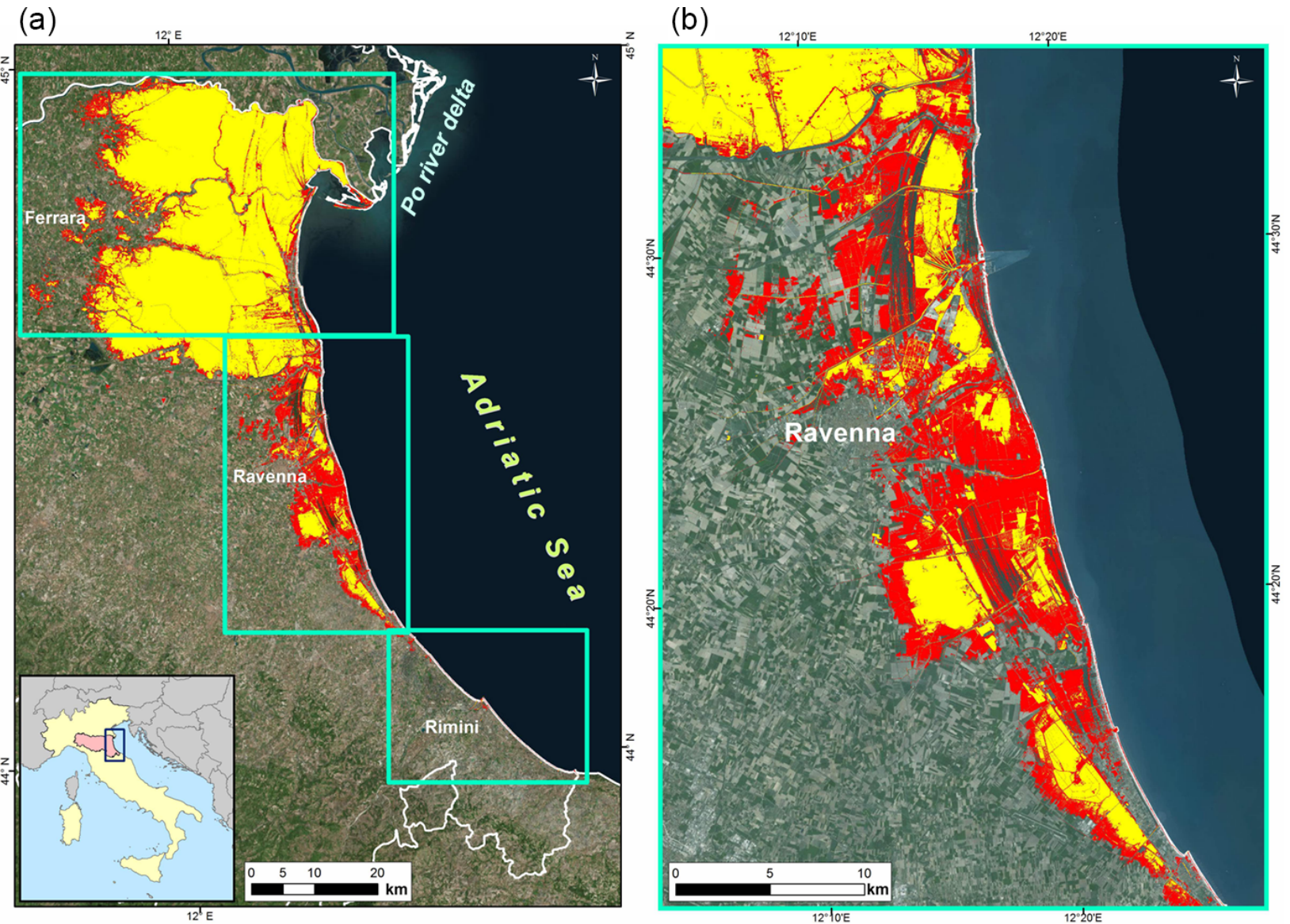

Figure 5. Results for the simulations in CS1 on the E-R coastal plain scale (a) and for the area of Ravenna (b). Lands that are currently located below sea level are evidenced in yellow. New areas predicted to be located below sea level in 2100 are marked in red.

portions of urban areas are involved, especially in the municipality of Bellaria-Igea Marina and north of the Rimini harbour.

\subsubsection{Area 3}

Area 3 (Fig. 8) turns out to be the most critical of the E$\mathrm{R}$ coast as a result of the high rate of subsidence that characterises its northern portion, between Cervia and the Uniti river mouth. Here we observe the most significant increase $(+248 \%)$ in the floodable area in the year 2100 with respect to 2012 (P2-DTM12) as a result of current subsidence rates. When the expected sea-level rise is also taken into consideration, the increase rises up to +308 and to $+404 \%$ for the $\mathrm{L}$ and the $\mathrm{H}$ scenarios, respectively. These values evidence that the effect of sea-level rise is marginal with respect to subsidence, at least for scenario L. However, the storm surge would also flood the entire coast in this area. The frontal ingression could extend several hundred metres, exceeding $0.5 \mathrm{~km}$ in the P2-DTM12 scenario, thus involving large urban areas.

\subsubsection{Area 4}

In Area 4 (Fig. 9), the scenarios projected to year 2100 are sharpened by the presence of wide low-elevation regions, with some of them currently below mean sea level. This is exacerbated by two factors. The first is the total absence of natural or artificial defences such as dunes and embankments that could counteract the marine action. The second is the high rate of subsidence, reaching 15 and even $20 \mathrm{~mm} \mathrm{yr}^{-1}$ at some locations like Porto Corsini, Lido Adriano and Lido di Dante. The increase in the floodable area, only as a result of the subsidence, would be of $\sim 153 \%$ relative to P2DTM12. This rises to +214 and $+294 \%$ when the predicted sea-level rise in 2100 is taken into account, according to the low-end and high-end scenarios, respectively. In this model, the ingression would occur along the whole coast, involving urban areas as well as natural reserves. The expected inner limit for the areas reached by the flooding would move inland by about $1 \mathrm{~km}$ with respect to P2-DTM12. We should note, however, that the recent assessment by Bissoli et al. (2012) for the subsidence in this area has revealed a strong decrease to values of $6-7 \mathrm{~mm} \mathrm{yr}^{-1}$. This suggests that these 


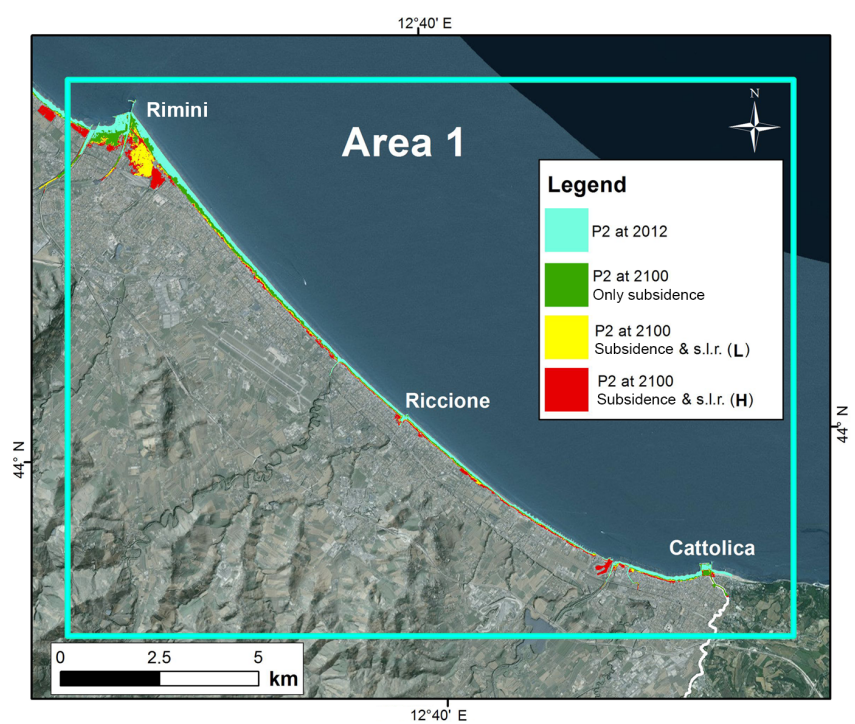

Figure 6. Floodable regions across Area 1 in the case of a storm surge for case P2 in 2100. The assumptions in modelling are colour coded in the inset. In Figs. 6-10 "best" and "worst" refer to the L and $\mathrm{H}$ scenarios described in the body of the paper, respectively. Sea-level rise is represented by s.l.r.

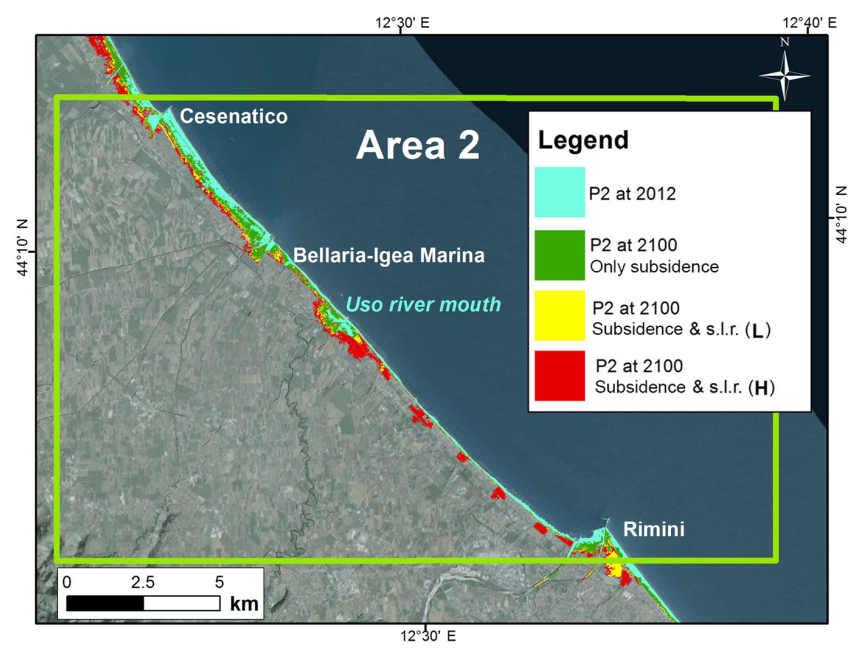

Figure 7. The same as in Fig. 6, but for Area 2.

proposed scenarios could be revised in the near future and possibly replaced by more optimistic ones.

\subsubsection{Area 5}

The results for Area 5, shown in the map of Fig. 10, indicate an increase of $\sim 59 \%$ in the floodable area in the case of a storm surge with a return a period of 100 years (P2 in Table 4) when only the effects of land subsidence are considered (see green coloured areas). This result is crucial, since currently in the Po delta area the subsidence is assumed to be almost completely natural (Teatini et al., 2011b), with rates

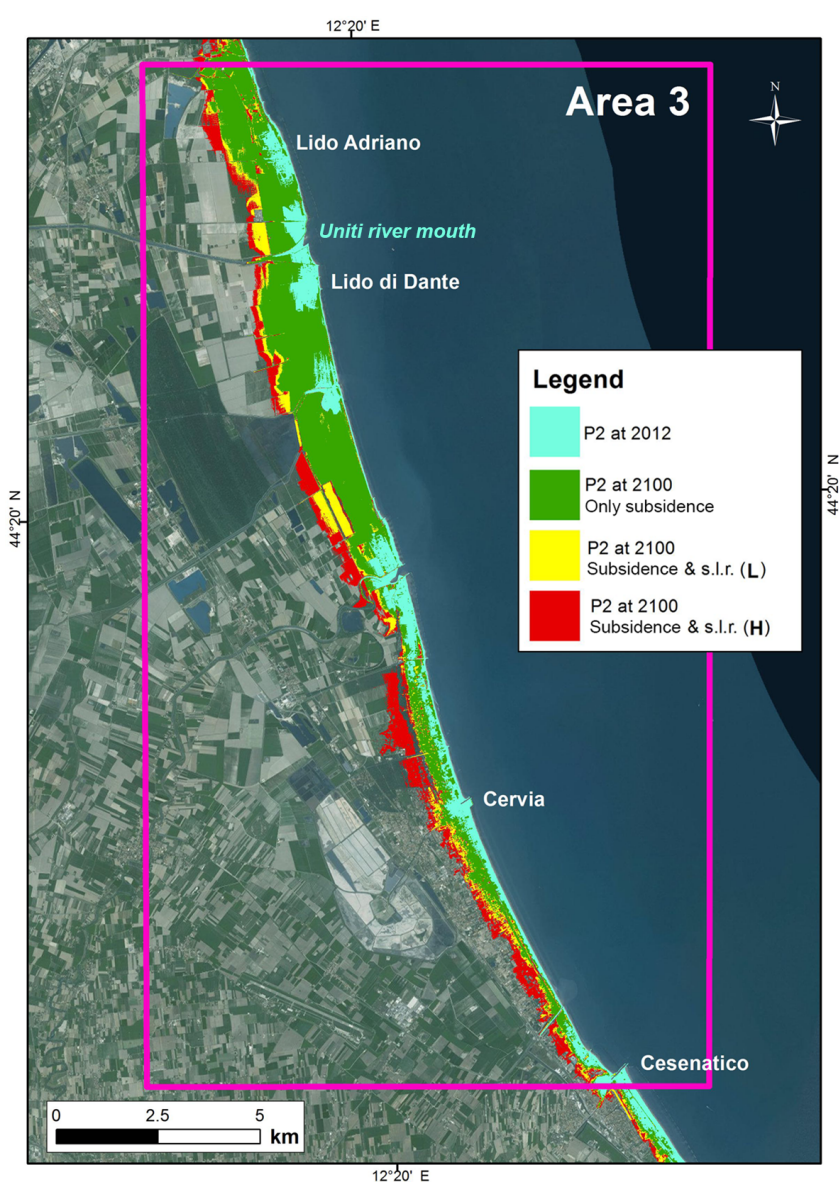

Figure 8. The same as in Fig. 6, but for Area 3.

that locally reach $11 \mathrm{~mm} \mathrm{yr}^{-1}$. Accordingly, it appears unlikely to expect a reduction, neither natural nor induced, in the next 100 years. If we include the effect of the predicted sea-level rise in 2100 , the percent increase in the floodable areas rises to 102 and $214 \%$ for the $\mathrm{L}$ and $\mathrm{H}$ scenarios, respectively (yellow and red areas). It should be noted that a large portion of those areas that will become floodable in 2100 are currently protected by embankments. The above estimates imply that the current artificial defences would loose their functionality in 2100 . Further considerations relate with the inward displacement of more than $2 \mathrm{~km}$ of the floodable area boundaries relative to the P2-DTM12 predictions. This would in fact largely involve urbanised areas although the inward propagation of the sea would be localised at weak or low points along the embankments. As a result, constant and efficient maintenance is required for the embankments to counteract the effects of subsidence and of future storm surges. 


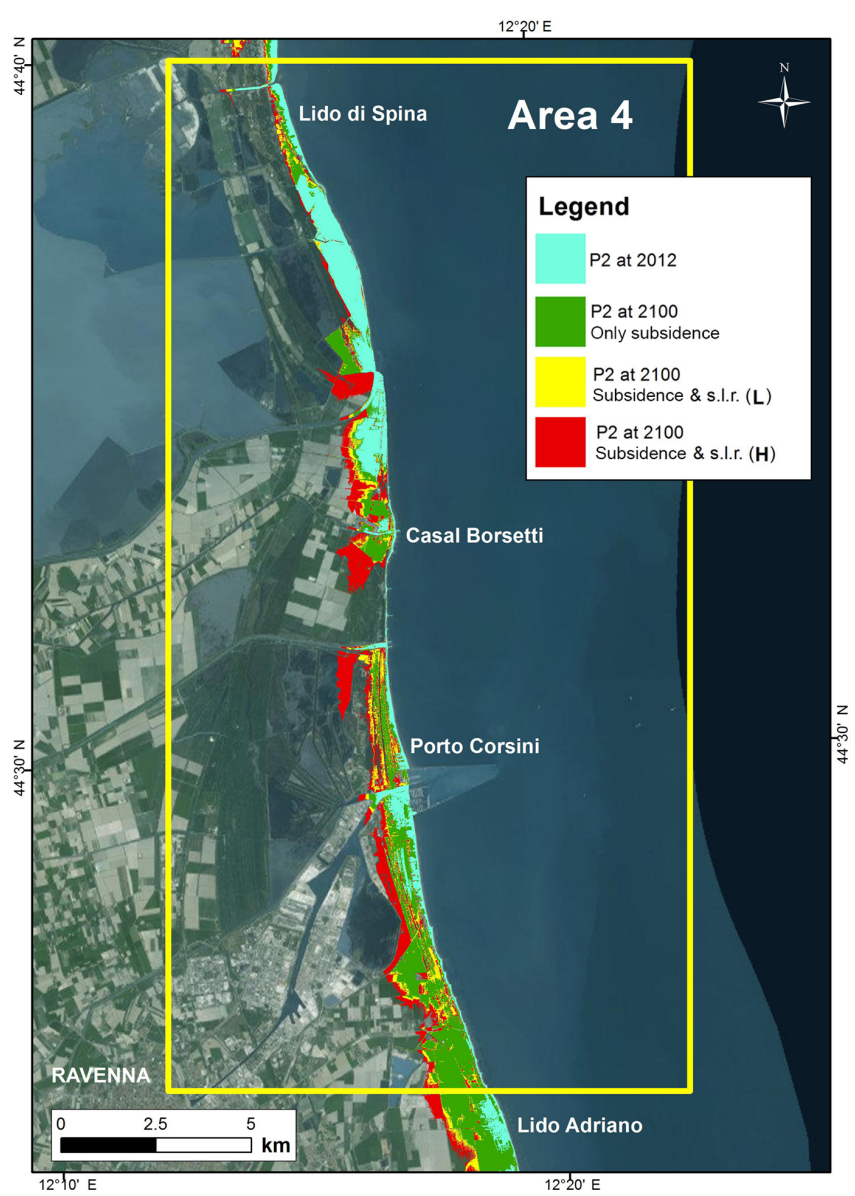

Figure 9. The same as in Fig. 6, but for Area 4.

Table 7. Regional floodable areas in the case of storm surges for case P2 described in Table 4. The increase in the flooded area is relative to P2-DTM12.

\begin{tabular}{lrr}
\hline Case & $\begin{array}{r}\text { Flooded area } \\
\left(\mathrm{km}^{2}\right)\end{array}$ & $\begin{array}{r}\text { Increase } \\
(\%)\end{array}$ \\
\hline P2-DTM12 & 29 & \\
$2100^{\mathrm{a}}$ & 59 & 95 \\
$2100^{\mathrm{b}}$ & 72 & 133 \\
$2100^{\mathrm{c}}$ & 105 & 236 \\
\hline
\end{tabular}

a Only subsidence; ${ }^{b}$ subsidence and sea-level rise (L scenario); ${ }^{\mathrm{c}}$ subsidence and sea-level rise (H scenario).

\subsection{A regional synthesis for CS2}

Based on the analysis above, the combined effect of subsidence and sea-level rise in terms of enlarged floodable areas in 2100 can be summarised as follows (see Table 7). (i) Land subsidence plays a non-negligible role, leading to an increase in the floodable areas of $\sim 95 \%$ with respect to that predicted by P2-DTM12 along the entire E-R coastal plain in the year 2100; (ii) the superimposition of the $\mathrm{H}$ scenario for sea level

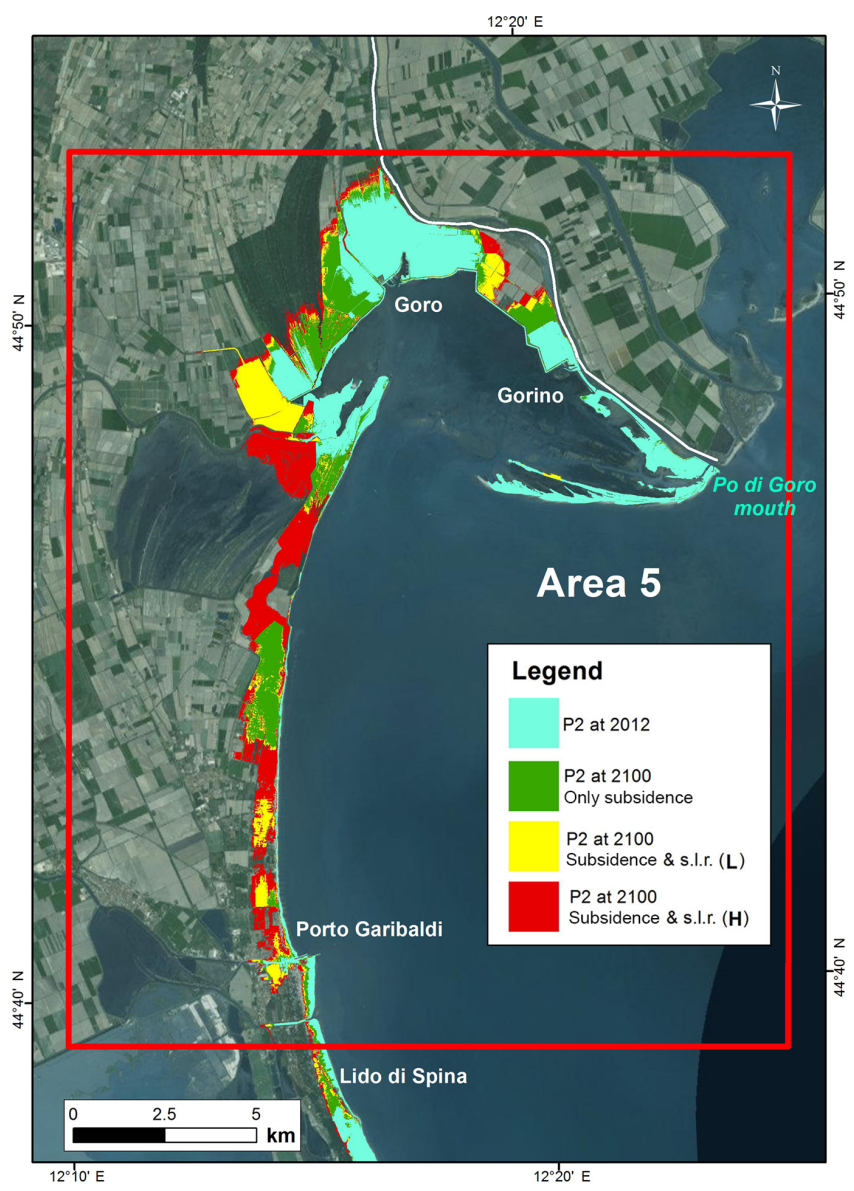

Figure 10. The same as in Fig. 6, but for Area 5.

would enlarge the extension of the floodable areas in the case of the P2 event by more than 2 times $(+236 \%)$ with respect to P2-DTM12; (iii) the most critical portion of the E-R coast in terms of the increase in the floodable area is recognised as the central one, corresponding to areas 3 and $4-$ in this respect Area 1 turns out to be the less critical; (iv) in the E-R coast portion that extends between Casal Borsetti and Cervia (areas 3 and 4), the increase is dominated by subsidence which tapers the effect related to sea-level rise; (v) to the north, areas where subsidence dominates are alternated with those in which sea level has a major role. Those are mainly localised where defences are in place but gaps are present.

For a correct interpretation of our results, it should be noted that in CS1 we have only considered the combined effect of subsidence and sea-level rise, while in CS2 we have also included the effects of storm surges. In both cases, we are omitting the effects of the coastal morphodynamics and of the solid transport by the sea and by the rivers, as well as the anthropogenic factors that could concur in modifying the landscape by the end of the century. These, in some cases, could contribute to mitigate the effects of the predicted sea ingression. 


\section{Discussion}

Our study relies upon a number of important assumptions regarding the role and the rate of land subsidence, the morphological conditions and the adopted sea-level projections. Each of these assumptions implies some uncertainties, which requires some further discussion.

The surmise of a linear trend of subsidence can be motivated by observing that the major temporal variations in the rates are observed in confined areas, where groundwater exploitation and anthropic impact are particularly strong (for various specific case studies, see for example Le Mouélic et al., 2005; Wang et al., 2012; Raucoules et al., 2013). In the remaining parts of the E-R coastal plain, which cover most of the study area, the subsidence rates measured during the different monitoring campaigns are comparable. We interpret this spatial and temporal distribution as a constant background signal, likely due to natural subsidence, with overlapping local perturbations due to human activity. These are difficult to model because of the large number of variables and the complexity of the driving processes. In addition, measures imposed by the Emilia-Romagna Regional Administration over the last 30 years to reduce the fluid extraction have allowed for a progressive stabilisation of subsidence rates in most of the critical areas. Thus, assuming that the measures will be maintained, future rates of subsidence will not be likely to exceed the current ones. Current subsidence rates were then used in modelling as they well describe the geodynamic condition of the E-R coast on a regional scale, pointing out the present state of the highly subsiding areas. Thus, the results in Table 5 reflect the benefits of the ongoing adaptation strategy consisting in the mitigation of subsidence through reduced fluid extractions.

Concerning the morphological changes, it was chosen to consider a rigid substrate modified only by the subsidence (translation) - since, at present, it has not been possible to apply a dynamic modelling approach also integrating longterm coastal evolution (e.g. beach changes) on the regional scale - or land use projection. In this view, the model excludes the natural adaptation of the coastal system as well since it is based on the assumption of "no intervention" by man (no nourishment, no upgrading of the coastal defence systems, etc.).

Another important source of uncertainty arises from the sea-level projections along the E-R coastal plain. In this work, we have relied upon projections based on global scenarios reported in the IPCC AR5 (Church et al., 2013) and corresponding to specific RCPs. However, recent ensemble simulations from Adloff et al. (2015) have shown that projections within the Mediterranean Sea are particularly sensitive to the conditions assumed in the nearby Atlantic region, which are uncertain in the general circulation models. According to Slangen et al. (2017), the minimum uncertainty associated with the sea-level projections to the year 2100 is $\pm \sim 10 \mathrm{~cm}$, which is comparable to the uncertainty asso- ciated with our projections in Table 2, for all the possible RCPs. This confirms the need, in future studies about the impacts of sea-level rise along the E-R coastal plain, for highquality regional ocean models.

\section{Conclusions}

In this work we have performed a GIS analysis aimed at identifying those areas of the E-R coastal plain that would suffer, by the end of this century, from an increased vulnerability in response to land subsidence and sea-level rise. These will cause the loss of large portions of emerged land, in particular beaches, wetlands and dunes. While the first would have a relevant impact on the tourism industry of the region, wetlands and dunes would threaten valuable ecosystems, which is essential for the preservation of nature and life. A second major effect would be the enlargement of the portions of land exposed to water flooding in the case of storm surges.

The effects of sea-level rise have been modelled in terms of land loss and the increase in floodable areas, assuming storm surges with a return period of 100 years. The distribution of floodable areas has been compared with current scenarios designed by the RER in the framework of the DLGS 49/2010, national transposition of the Flood Directive (EU 2007/60). The high quality of the datasets employed both on regional and local scales and their enhanced spatial resolution have allowed for a detailed analysis, with a focus on the effect of the single components. The eustatic effect coupled with subsidence has, in the context of the E-R plain, a relevant long-term impact, although in different ways along the coast. The subsidence appears to be the most significant cause in some areas, such a the Ravenna district. The combination of a $55 \mathrm{~cm}$ increase in sea level (H scenario, based on the IPCC AR5 projections) with a widespread subsidence that is expected to affect the entire coastal area at different rates results in an increase of about $346 \mathrm{~km}^{2}$ in the land that could be partly below mean sea level. The new areas below mean sea level could be directly connected to the sea and therefore potentially floodable. This would lead to an increase in the former wetlands reclaimed at the beginning of the last century.

In a step forward, we have combined the above results for the $\mathrm{L}(+23 \mathrm{~cm})$ and $\mathrm{H}(+55 \mathrm{~cm})$ sea-level scenarios with the predicted effects of coastal storm phenomena, i.e. total seawater level, based on the model in_CoastFlood with scenarios with return period of 100 years. The results have evidenced that (i) subsidence and storm surges would lead to an increase from 29 to $59 \mathrm{~km}^{2}$ in floodable areas in 2100 ; (ii) when subsidence and storm surges are combined with sea-level rise, the increase in floodable areas is +133 and $+236 \%$ for the $\mathrm{L}$ and $\mathrm{H}$ scenarios, respectively. In our study, we did not consider possible changes in the current observed rates of subsidence and storminess nor any human intervention to adapt the existing coastal defence to the evolving 
shape of the coastline. This work, indeed, discusses the scenario of maximum vulnerability for the case of no intervention, with the aim of defining the most appropriate actions to be applied in the updating of the FD plan, which is expected for the year 2021.

Through the integration of the above results with the flooding maps produced in the framework of the DGLS 49/2010, it has been possible to compare the current situation with possible future scenarios. The methodology implemented, which demands relatively limited computational resources, will allow new analyses and further maps to plan new possible mitigation actions as well. This would, however, leave the E-R coastal plain exposed to a certain level of risk, as a result of its natural setting and geology. We expect that the output of our analysis will support the planned activities for the second stage of the Flood Directive 2007/60, i.e. the provision of updated hazard and risk maps by 2019. These should include, in fact, the risks assessment driven by the climate change, which was not presented in the first cycle of the directive application, in order to identify mitigation and adaptation measures. Likewise, we expect that this work can provide an important contribution to the working group on the Regional Climate Change Strategy, which aims to develop an action plan by 2018. In this respect, this work can be considered the starting point for decision makers as well as for the scientific community to define the areas exposed to a major risk, the possible actions to mitigate the predicted risks, and the strategies to handle the forthcoming strong surges and flooding.

Code and data availability. The codes and data employed in this work are available on request from Luisa Perini.

Author contributions. The work presented here was carried out in collaboration between all authors. LP, LC and PL defined the research theme and designed most of the methods and experiments. MO, GG and GS have designed some of the methods and experiments and have contributed to the interpretation of the results. All authors have contributed to write the paper. All authors have contributed to, seen and approved the manuscript.

Competing interests. The authors declare that they have no conflict of interest.

Acknowledgements. We thank Goneri Le Cozannet and an anonymous reviewer for their very helpful suggestions. Sea-level projections have been extracted from the Integrated Climate Data Center (ICDC, http://www.icdc.zmaw.de/) of the Hamburg University on October 2015. We also thank Rocco Coronato for his help during the editing process. GG and GS are partly supported by research grants of the Department of Pure and Applied Sciences (DiSPeA) of the Urbino University "Carlo Bo"
(CUPs H32I160000000005 and H32I15000160001). Some of the figures have been drawn using the Generic Mapping Tools (GMT) (Wessel et al., 2013).

Edited by: Oded Katz

Reviewed by: Goneri Le Cozannet and one anonymous referee

\section{References}

Adloff, F., Somot, S., Sevault, F., Jordà, G., Aznar, R., Déqué, M., Herrmann, M., Marcos, M., Dubois, C., Padorno, E., AlvarezFanjul, E., and Gomis, D.: Mediterranean Sea response to climate change in an ensemble of twenty first century scenarios, Clim. Dynam., 45, 2775-2802, 2015.

Antonioli, F., Ferranti, L., Fontana, A., Amorosi, A., Bondesan, A., Braitenberg, C., Dutton, A., Fontolan, G., Furlani, S., Lambeck, K., Mastronuzzi, G., Monaco, C., Spada, G., and Stocchi, P.: Holocene relative sea-level changes and vertical movements along the Italian and Istrian coastlines, Quatern. Int., 206, 102133, 2009.

Antonioli, F., Anzidei, M., Amorosi, A., Presti, V. L., Mastronuzzi, G., Deiana, G., De Falco, G., Fontana, A., Fontolan, G., Lisco, S., Marsico, A., Moretti, M., Orru, P. E., Sannino, G. M., Serpelloni, E., and Vecchio, A.: Sea-level rise and potential drowning of the Italian coastal plains: Flooding risk scenarios for 2100, Quaternary Sci. Rev., 158, 29-43, 2017.

Armaroli, C., Ciavola, P., Masina, M., and Perini, L.: Run-up computation behind emerged breakwaters for marine strom risk assessment, J. Coastal Res., 56, 1612-1616, 2009.

Armaroli, C., Ciavola, P., Perini, L., Calabrese, L., Lorito, S., Valentini, A., and Masina, M.: Critical storm thresholds for significant morphological changes and damage along the Emilia-Romagna coastline, Italy, Geomorphology, 143, 34-51, 2012.

Aucelli, P. P. C., Di Paola, G., Incontri, P., Rizzo, A., Vilardo, G., Benassai, G., Buonocore, B., and Pappone, G.: Coastal inundation risk assessment due to subsidence and sea level rise in a Mediterranean alluvial plain (Volturno coastal plain-southern Italy), Estuar. Coast. Shelf Sci., 198, 597-609, 2016.

Barends, F. B., Carbognin, L., Gambolati, G., and Steedman, R. S.: LAND SUBSIDENCE (Special Volume), Proceedings of Seventh International Symposium on Land Subsidence, 23-28 October 2005, Shanghai, China, Millpress Science Publishers, Rotterdam, the Netherlands, 2005.

Bissoli, R., Pellegrino, I., and Rapino, A.: Rilievo della subsidenza nella pianura emiliano-romagnola. Relazione finale, seconda fase, Tech. rep., Regione Emilia-Romagna, ARPA-RER, Bologna, Italy, 2012.

Bonaduce, A., Pinardi, N., Oddo, P., Spada, G., and Larnicol, G.: Sea-level variability in the Mediterranean Sea from altimetry and tide gauges, Clim. Dynam., 47, 2851-2866, 2016.

Bondesan, M., Castiglioni, G., Elmis, C., Gabbianelli, G., Marocco, R., Pirazzoli, P., and Tomasin, A.: Coastal areas at risk from storm surges and sea-level rise in northeastern Italy, J. Coastal Res., 11, 1354-1379, 1995.

Bonsignore, F., Cristofori, D., Costantino, R., Errigo, D., Porrelli, M. G., and Laghi, A.: Analisi preliminare degli effetti dei prelievi di acque sotterranee sull'evoluzione recente del fenomeno della 
subsidenza in Emilia-Romagna, Tech. rep., Regione EmiliaRomagna, ARPA Ingegneria Ambientale, Bologna, Italy, 2008.

Brázdil, R., Pfister, C., Wanner, H., Von Storch, H., and Luterbacher, J.: Historical climatology in Europe - the state of the art, Climatic Change, 70, 363-430, 2005.

Bruckner, E.: Klima-Schwankungen seit 1700 nebst Bemerkungen über die Klimaschwankungen der Diuvialzeit, Geographische Abhandlungen, 14, E. Hölzel, Wien, Austria, 325 pp., 1890.

Calabrese, L., Cibin, U., and Perini, L.: Evoluzione del sistema marino-costiero nel contesto geologico-climatico, in: Il Sistema Mare-Costa dell'Emilia-Romagna, edited by: Perini, L. and Calabrese, L., 137-154, Pendragon, Bologna, Italy, 2010.

Carminati, E. and Di Donato, G.: Separating natural and anthropogenic vertical movements in fast subsiding areas: the Po plain (N. Italy) case, Geophys. Res. Lett., 26, 2291-2294, 1999.

Cazenave, A. and Cozannet, G. L.: Sea level rise and its coastal impacts, Earth's Future, 2, 15-34, 2014.

Cerenzia, I., Putero, D., Bonsignore, F., Galassi, G., Olivieri, M., and Spada, G.: Historical and recent sea level rise and land subsidence in Marina di Ravenna, northern Italy, Ann. Geophys.-Italy, 59, P0546, https://doi.org/10.4401/ag-7022, 2016.

Church, J., Clark, P., Cazenave, A., Gregory, J., Jevrejeva, S., Levermann, A., Merrifield, M., Milne, G., Nerem, R., Nunn, P., Payne, A., Pfeffer, W., Stammer, D., and Unnikrishnan, A.: Sea Level Change, in: Climate Change 2013: The Physical Science Basis. Contribution of Working Group I to the Fifth Assessment Report of the Intergovernmental Panel on Climate Change, edited by: Stocker, T., Qin, D., Plattner, G.-K., Tignor, M., Allen, S., Boschung, J., Nauels, A., Xia, Y., Bex, V., and Midgley, P., 11381191, Cambridge University Press, Cambridge, UK, 2013.

Ciavola, P., Ferreira, O., Haerens, P., Van Koningsveld, M., and Armaroli, C.: Storm impacts along European coastlines. Part 2: lessons learned from the MICORE project, Environ. Sci. Pol., 14, 924-933, 2011.

Clarke, L., Edmonds, J., Jacoby, H., Pitcher, H., Reilly, J., and Richels, R.: Scenarios of greenhouse gas emissions and atmospheric concentrations, US Climate Change Science Program and the Subcommittee on Global Change Research, Department of Energy, Office of Biological \& Environmental Research, Washington D.C., USA, p. 6, 2007.

Correggiari, A., Roveri, M., and Trincardi, F.: Late Pleistocene and Holocene evolution of the north Adriatic Sea, Il Quaternario, 9, 697-704, 1996.

Deserti, M., Chiggiato, J., Valentini, A., Perini, L., Cibin, U., Lucani, P., Calabrese, L., Lorito, S., Ciavola, P., Gardelli, M., and Armaroli, C.: Analysis of correlation between coast evolution and meteo-marine climatology. CADSEALAND WP04: Integrated informative system to support protection strategies. Deliverable 4.5, Tech. rep., Annali Idrologici del Servizio Idrografico e Mareografico Nazionale, Bologna, Italy, 115 pp., 2006.

De Zolt, S., Lionello, P., Nuhu, A., and Tomasin, A.: The disastrous storm of 4 November 1966 on Italy, Nat. Hazards Earth Syst. Sci., 6, 861-879, https://doi.org/10.5194/nhess-6861-2006, 2006.

European Parliament and Council: Directive 2007/60/EC of the European Parliament and of the Council of 23 October 2007 on the assessment and management of flood risks, Official Journal of the European Union, L288, 27-34, 2007.
Friis-Christensen, E. and Lassen, K.: Length of the solar cycle: an indicator of solar activity closely associated with climate, Science, 254, 698-700, 1991.

Fujino, J., Nair, R., Kainuma, M., Masui, T., and Matsuoka, Y.: Multi-gas mitigation analysis on stabilization scenarios using AIM global model, Energ. J., 27, 343-353, 2006.

Galassi, G. and Spada, G.: Sea-level rise in the Mediterranean Sea by 2050: Roles of terrestrial ice melt, steric effects and glacial isostatic adjustment, Global Planet. Change, 123, 55-66, 2014a.

Galassi, G. and Spada, G.: Linear and non-linear sea-level variations in the Adriatic Sea from tide gauge records (1872-2012), Ann. Geophys.-Italy, 57, P0658, https://doi.org/10.4401/ag6536, 2014 b.

Gambolati, G., Giunta, G., Putti, M., Teatini, P., Tomasi, L., Betti, I., Morelli, M., Berlamont, J., De Backer, K., Decouttere, C., Monbaliu, J., Yu, C. S., Brøker, I., Christensen, E. D., Elfrink, B., Dante, A., and Gonella, M.: Coastal evolution of the Upper Adriatic Sea due to sea level rise and natural and anthropic land subsidence, in: CENAS: Coastline Evolution of the Upper Adriatic Sea due to Sea Level Rise and Natural and Anthropogenic Land Subsidence, 1-34, Springer, Dordrecht, the Netherlands, 1998.

Gambolati, G., Teatini, P., and Tomasi, L.: Coastline regression of the Romagna region, Italy, due to natural and anthropogenic land subsidence and sea level rise, Water Resour. Res., 35, 163-184, 1999.

Gonella, M., Teatini, P., Tomasi, L., and Gambolati, G.: Flood risk analysis in the Upper Adriatic Sea due to storm surge, tide, waves, and natural and anthropic land subsidence, in: CENAS: Coastline Evolution of the Upper Adriatic Sea due to Sea Level Rise and Natural and Anthropogenic Land Subsidence, edited by: Gambolati, G., 313-324, Springer, Dordrecht, the Netherlands, 1998.

Harley, M. D.: Coastal Storm Definition, in: Coastal Storms: Processes and Impacts, John Wiley \& Sons, Ltd, Chichester, UK, 1-21, 2017.

Harley, M. D., Valentini, A., Armaroli, C., Ciavola, P., Perini, L., Calabrese, L., and Marucci, F.: An early warning system for the on-line prediction of coastal storm risk on the Italian coastline, Coastal Engineering Proceedings, 1, 77, https://doi.org/10.9753/icce.v33.management.77, 2012.

Hinkel, J., Lincke, D., Vafeidis, A. T., Perrette, M., Nicholls, R. J., Tol, R. S., Marzeion, B., Fettweis, X., Ionescu, C., and Levermann, A.: Coastal flood damage and adaptation costs under 21st century sea-level rise, P. Natl. Acad. Sci. USA, 111, 3292-3297, 2014.

Hinkel, J., Jaeger, C., Nicholls, R. J., Lowe, J., Renn, O., and Peijun, S.: Sea-level rise scenarios and coastal risk management, Nature Climate Change, 5, 188-190, 2015.

IDROSER S.p.A.: Progetto di Piano per la difesa dal mare e la riqualificazione ambientale del litorale della Regione EmiliaRomagna, Tech. rep., Regione Emilia-Romagna, Bologna, Italy, 1996.

Intergovernmental Panel on Climate Change: The supplementary report to the IPCC scientific assessment, Intergovernmental Panel on Climate Change, Cambridge Univ. Press, Cambridge, UK, 1992.

Lambeck, K., Antonioli, F., Anzidei, M., Ferranti, L., Leoni, G., Scicchitano, G., and Silenzi, S.: Sea level change along the Ital- 
ian coast during the Holocene and projections for the future, Quatern. Int., 232, 250-257, 2011.

Le Mouélic, S., Raucoules, D., Carnec, C., and King, C.: A least squares adjustment of multi-temporal InSAR data, Photogramm. Eng. Rem. S., 71, 197-204, 2005.

Lionello, P., Galati, M., and Elvini, E.: Extreme storm surge and wind wave climate scenario simulations at the Venetian littoral, Phys. Chem. Earth A/B/C, 40, 86-92, 2012.

Lorito, S., Calabrese, L., Perini, L., and Cibin, U.: Uso del suolo della costa, Il sistema mare-costa dell'Emilia-Romagna. Pendragon, Bologna, Italy, 109-118, 2010.

Malguzzi, P., Grossi, G., Buzzi, A., Ranzi, R., and Buizza, R.: The 1966 "century" flood in Italy: A meteorological and hydrological revisitation, J. Geophys. Res.-Atmos., 111, D24106, https://doi.org/10.1029/2006JD007111, 2006.

Marabini, F., Veggiani, A., Yunshan, Q., and Shuxi, C.: Climatic variations in the coastal zone - Comparison between the Po River delta (Adriatic Sea, Italy) and the Huanghe River delta (Bohai Sea, China), Chin. J. Oceanol. Limn., 11, 193-206, 1993.

Masina, M. and Ciavola, P.: Analisi dei livelli marini estremi e delle acque alte lungo il litorale ravennate, Studi costieri, 18, 87-101, 2011.

Nicholls, R. J. and Cazenave, A.: Sea-level rise and its impact on coastal zones, Science, 328, 1517-1520, 2010.

Nicholls, R. J., Hoozemans, F. M., and Marchand, M.: Increasing flood risk and wetland losses due to global sea-level rise: regional and global analyses, Glob. Environ. Change, 9, S69-S87, 1999.

Perini, L. and Calabrese, L.: Il sistema mare-costa dell'EmiliaRomagna, vol. 20, Pendragon, Bologna, Italy, 2010.

Perini, L., Calabrese, L., Deserti, M., Valentini, A., Ciavola, P., and Armaroli, C.: Le mareggiate e gli impatti sulla costa in EmiliaRomagna, 1946-2010, edited by: Perini, L., Calabrese, L., Deserti, M., Valentini, M., Ciavola, P., and Armaroli, C., Regione Emilia-Romagna, Bologna, Italy, 2011.

Perini, L., Calabrese, L., Salerno, G., and Luciani, P.: Sea-flood hazard mapping in Emilia-Romagna, in: Atti della 7th EUREGEO Conference, 12-15 June 2012, Bologna, Italy, vol. 1, 334-335, 2012.

Perini, L., Calabrese, L., Salerno, G., Ciavola, P., and Armaroli, C.: Evaluation of coastal vulnerability to flooding: comparison of two different methodologies adopted by the EmiliaRomagna region (Italy), Nat. Hazards Earth Syst. Sci., 16, 181194, https://doi.org/10.5194/nhess-16-181-2016, 2016.

Pieri, M. and Groppi, G.: Subsurface geological structure of the Po Plain, Progetto Finalizzato Geodinamica/Sottoprogetto Modello Strutturale, Consiglio Nazionale delle Ricerche, Italian CNR, Bologna, Italy, 414 pp., 1981.

Pirazzoli, P.: Bora e acqua alta, Acqua \& Aria, 10, 1115-1118, 1981.

Raucoules, D., Le Cozannet, G., Wöppelmann, G., De Michele, M., Gravelle, M., Daag, A., and Marcos, M.: High nonlinear urban ground motion in Manila (Philippines) from 1993 to 2010 observed by DInSAR: implications for sea-level measurement, Remote Sens. Environ., 139, 386-397, 2013.

Riahi, K., Grübler, A., and Nakicenovic, N.: Scenarios of long-term socio-economic and environmental development under climate stabilization, Technol.Forecast. Soc., 74, 887-935, 2007.

Ricci Lucchi, F., Colalongo, M. L., Cremonini, G., Gasperi, G., Iaccarino, S., Papani, G., Raffi, S., and Rio, D.: Evoluzione sedi- mentaria e paleogeografica nel margine appenninico, Guida alla geologia del margine appenninico-padano, Soc. Geol. It., 7, 1746, 1982.

Salerno, G., Perini, L., Calabrese, L., and Luciani, P.: Mapping of flood risk in Emilia-Romagna coastal areas, in: LXXXVI Congresso della Società Geologica Italiana, Rende (CS), Italy, https://doi.org/10.13140/2.1.1703.7766, 2012.

Slangen, A., Adloff, F., Jevrejeva, S., Leclercq, P., Marzeion, B., Wada, Y., and Winkelmann, R.: A review of recent updates of sea-level projections at global and regional scales, Surveys in Geophysics, 38, 385-406, 2017.

Spada, G. and Galassi, G.: New estimates of secular sea-level rise from tide gauge data and GIA modeling, Geophys. J. Int., 191, 1067-1094, https://doi.org/10.1111/j.1365-246X.2012.05663.x, 2012.

Stocchi, P. and Spada, G.: Influence of glacial isostatic adjustment upon current sea level variations in the Mediterranean, Tectonophysics, 474, 56-68, 2009.

Teatini, P., Ferronato, M., Gambolati, G., Bertoni, W., and Gonella, M.: A century of land subsidence in Ravenna, Italy, Environ. Geol., 47, 831-846, 2005.

Teatini, P., Castelletto, N., Ferronato, M., Gambolati, G., Janna, C., Cairo, E., Marzorati, D., Colombo, D., Ferretti, A., Bagliani, A., and Bottazzi, F.: Geomechanical response to seasonal gas storage in depleted reservoirs: A case study in the Po River basin, Italy, J. Geophys. Res.-Earth, 116, F02002, https://doi.org/10.1029/2010JF001793, 2011a.

Teatini, P., Tosi, L., and Strozzi, T.: Quantitative evidence that compaction of Holocene sediments drives the present land subsidence of the Po Delta, Italy, J. Geophys. Res.-Sol. Ea., 116, B08407, https://doi.org/10.1029/2010JB008122, 2011 b.

Trincardi, F., Barbanti, A., Bastianini, M., Benetazzo, A., Cavaleri, L., Chiggiato, J., Papa, A., Pomaro, A., Sclavo, M., Tosi, L., and Umgiesser, G.: The 1966 flooding of Venice: What time taught us for the future, Oceanography, 29, 178-186, https://doi.org/10.5670/oceanog.2016.87, 2016.

Van Vuuren, D. P., Den Elzen, M. G., Lucas, P. L., Eickhout, B., Strengers, B. J., van Ruijven, B., Wonink, S., and van Houdt, R.: Stabilizing greenhouse gas concentrations at low levels: an assessment of reduction strategies and costs, Climatic Change, 81, 119-159, 2007.

Veggiani, A.: L'ottimo climatico medievale in Europa: testimonianze lungo la fascia costiera Padano-Adriatica, Studi Romagnoli, 37, 3-26, 1986.

Wang, J., Gao, W., Xu, S., and Yu, L.: Evaluation of the combined risk of sea level rise, land subsidence, and storm surges on the coastal areas of Shanghai, China, Climatic change, 115, 537558, 2012.

Wessel, P., Smith, W. H., Scharroo, R., Luis, J., and Wobbe, F.: Generic Mapping Tools: improved version released, Eos, Transactions American Geophysical Union, 94, 409-410, 2013.

Wolff, C., Vafeidis, A. T., Lincke, D., Marasmi, C., and Hinkel, J.: Effects of Scale and Input Data on Assessing the Future Impacts of Coastal Flooding: An Application of DIVA for the Emilia-Romagna Coast, Frontiers in Marine Science, 3, 41, https://doi.org/10.3389/fmars.2016.00041, 2016. 